\title{
PERSISTENSI PENGANGGURAN DI INDONESIA DAN UPAYA PENANGGULANGANNYA BERDASARKAN ANALISIS DATA MIKRO
}

\author{
Mulyana Soekarni \\ Iman Sugema \\ Priyo R. Widodo ${ }^{1}$
}

\begin{abstract}
This study has three main objectives namely: (1) examine the existence of the persistence of unemployment in Indonesia; (2) examine the factors that cause the persistence of unemployment in Indonesia and in some sample areas, and (3) formulate strategies and policy measures needed to reduce the level of unemployment.

To achieve these objectives the activities we do is an empirical analysis through the modeling of Econometrics, unemployment accounting, and descriptive statistics. Meanwhile, the data used are secondary data and regional macroeconomic and primary data collected through interviews with workers, the unemployed, firms, bureaucrats, and unions.

The study concludes that the persistence of unemployment in Indonesia is disequilibrium persistent unemployment without self correcting mechanism, which means that the persistence occurred outside the labor market equilibrium and has no automatic mechanism to get to the point of equilibrium. In addition, persistence is the result of the slow process of capital accumulation, wage rigidity, the length of job search, and the inertia caused by institutional factors of labor market.

The main implication of this study are: (1) the need to improve the quality of growth through hands-on strategy; (2) banking policy and capital markets can lead to acceleration of capital accumulation; (3) monetary policy is more focused on inflation targeting, (4) increased total factor productivity; (5) special incentives for labor-intensive sectors; (6) strengthening vocational education, and (7) antiunemployment programs that are regionally specific.
\end{abstract}

Keywords: Persistent unemployment, Disequilibrium, Wage rigidity, Job search, Indonesia. JEL Classification: J23, J31.

\footnotetext{
1 Penulis adalah anggota tim peneliti untuk penelitian ini, yang merupakan hasil kerjasama antara Pusat Pendidikan dan Studi Kebanksentralan (PPSK) - Bank Indonesia dengan International Center for Applied Finance and Economics (InterCAFE), Lembaga Penelitian dan Pemberdayaan Masyarakat Institut Pertanian Bogor.
} 


\section{PENDAHULUAN}

Pertumbuhan ekonomi Indonesia pada kurun waktu 2001-2005 menunjukkan tren yang meningkat, namun besarnya masih lebih rendah apabila dibandingkan dengan pertumbuhan yang pernah dicapai sebelum krisis (sekitar 7 persen). Pertumbuhan ekonomi saat ini masih ditopang oleh konsumsi masyarakat yang kontribusinya sekitar 68 persen dari total Produk Domestik Bruto (PDB).

Dilihat dari sisi ketenagakerjaan, angkatan kerja yang setiap tahun mengalami peningkatan tidak sepenuhnya dapat diserap dan pada gilirannya mengakibatkan peningkatan jumlah pengangguran. Grafik III.1 dan Grafik III.2 menunjukkan bahwa tingkat pengangguran di Indonesia menunjukkan tren yang meningkat kecuali pada tahun 2007. Peningkatan ini dikarenakan adanya rasionalisasi jumlah tenaga kerja pada beberapa sektor industri yang sebelumnya mampu menyerap banyak tenaga kerja seperti sektor industri tekstil dan garmen.

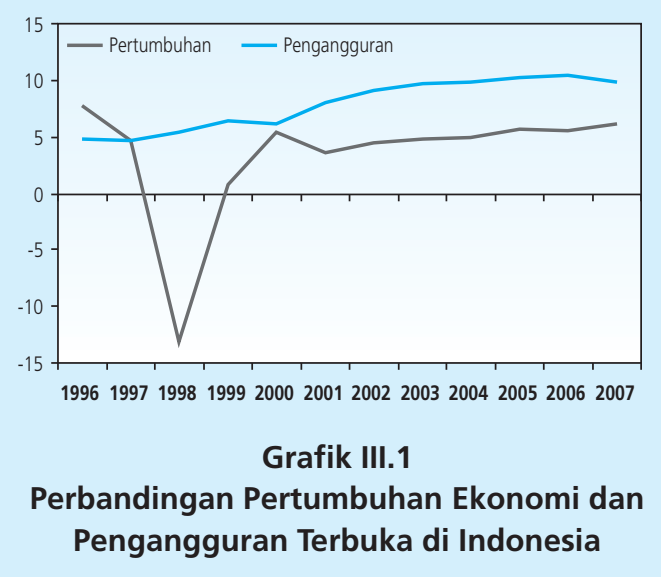

Penggangguran yang semakin meningkat dan relatif sulit untuk turun atau bahkan cenderung persisten akan menjadi beban bagi perekonomian Indonesia bila tidak diatasi dengan solusi yang tepat. Peningkatan pertumbuhan ekonomi dan indikator-indikator makro lainnya tampaknya belum cukup untuk digunakan sebagai dasar pengambilan kebijakan dalam menyelesaikan masalah pengangguran. Faktor-faktor tersebut antara lain terkait erat dengan aspek kebijakan pemerintah khususnya masalah hukum atau perundang-undangan, kualitas tenaga kerja, dan masalah serta kendala yang dihadapi oleh sektor industri.

Saat ini, perumusan kebijakan yang tepat untuk menanggulangi masalah pengangguran masih terkendala oleh berbagai hal antara lain; belum adanya peta permasalahan pengangguran 


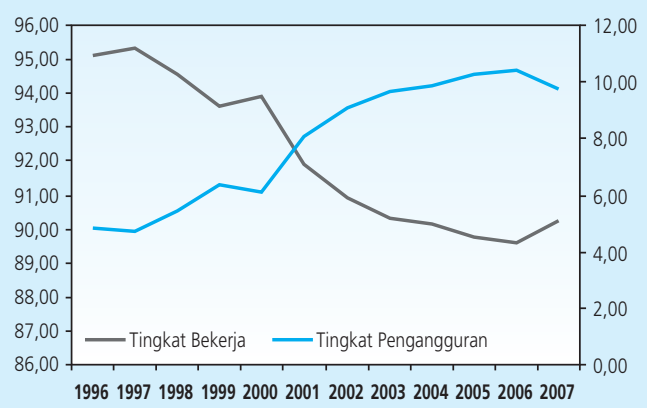

Grafik III.2

Tren Tingkat Bekerja

dan Tingkat Pengangguran di Indonesia

yang lengkap dan akurat; belum teridentifikasinya faktor-faktor yang mempengaruhi pengangguran; serta strategi dan langkah kebijakan yang belum tepat.

Paper ini mengulas hal-hal yang terkait dengan perumusan kebijakan penanggulangan masalah pengangguran; 3 diantaranya adalah (1) mengetahui apakah persistensi pengangguran terjadi di Indonesia; (2) faktor-faktor apa yang menyebabkan terjadinya persistensi pengangguran; serta (3) berbagai aspek yang terkait dengan solusi masalah penggangguran yang mencakup di antaranya kesiapan tenaga kerja, instrumen atau kebijakan dari pemerintah terutama kesiapan perangkat hukum dan kondisi yang dihadapi para pengusaha. Dengan demikian, diharapkan persistensi pengangguran di Indonesia dapat diatasi dengan sistematis dan menyeluruh. Bagian kedua dari paper ini membahas studi literatur tentang ketenagakerjaan, bagian ketiga mengulas metodologi, keempat analisis dan ditutup dengan bagian kesimpulan dan saran.

\section{TEORI}

Persistensi pengangguran dapat didefinisikan sebagai terjadinya kenaikan tingkat pengangguran secara terus menerus. Menurut Blanchard dan Summer (1986), persistensi pengangguran terjadi manakala penyesuaian (adjustment) terhadap tingkat kesetimbangan berjalan dengan lambat.

Walaupun dengan adjustmentyang lambat, tingkat pengangguran yang persisten memiliki kecenderungan untuk dapat kembali ke tingkat semula atau tingkat sebelumnya (mean 
reversion). Kondisi ini perlu dibedakan dengan hysteresis yang merupakan kondisi fluktuasi dalam pasar tenaga kerja yang memiliki dampak yang permanen terhadap tingkat pengangguran. Hal ini ditegaskan oleh Tolvi (2003) bahwa unemployment persistence atau unemployment hysteresis merupakan suatu fenomena di mana tingkat pengangguran di suatu wilayah meningkat dan diperlukan waktu yang cukup lama untuk mengembalikan pengangguran tersebut ke tingkat pengangguran semula, atau bahkan tingkat pengangguran ini tidak akan pernah kembali ke tingkat awal tersebut.

Studi literatur menunjukkan bahwa persistensi pengangguran disebabkan oleh beragam faktor (Tabel III.1 dan III.2). Assarsson dan Jansson (1995) dan Linblad (1997) menyatakan bahwa persistensi pengangguran dapat disebabkan oleh beberapa faktor: (1) persistensi pengangguran dapat disebabkan oleh natural rate shocks, (2) pengangguran dapat memiliki siklus dengan periode yang cukup lama, (3) guncangan siklikal dalam pengangguran dapat ditransmisikan menjadi pengangguran yang permanen, (4) kombinasi dari guncangan siklikal dan permanen dalam efek spill-over².

Blanchard dan Summers (1986) menemukan bahwa derajat persistensi lebih tinggi di negara-negara Eropa daripada di Amerika. Hasil riset tersebut diperkuat dengan hasil riset yang dilakukan Ledesma (2000) yang bertujuan untuk mengetahui apakah terjadi persisten atau hysteresis pengangguran antara kawasan Eropa dan Amerika. Estimasi dengan menggunakan Panel Unit Root digunakan untuk mendapatkan $t$-statistik yang mencerminkan derajat persistensi.

Tolvi (2003) menggunakan model ARFIMA (Autoregressive Fractionally Integrated Moving Average) dan LM (Langrange Multiplier) untuk data Finlandia. Hasil penelitiannya menunjukkan bahwa persistensi pengangguran untuk angkatan kerja muda lebih kecil dibandingkan angkatan kerja keseluruhan. Selain itu persistensi pengangguran pada kelompok wanita lebih kecil dibandingkan kelompok pria baik untuk kelompok usia muda maupun untuk angkatan kerja secara keseluruhan.

Steiner (2001) menggunakan pendekatan hazard rate ${ }^{3}$ dari pengangguran untuk menganalisa pasar tenaga kerja Jerman Barat. Data empiris menunjukkan bahwa hazard rate dari pengangguran mengalami penurunan seiring berjalannya waktu. Hal ini merupakan suatu bukti kuat yang mendukung hipotesis negative structural duration dependence ${ }^{4}$. Hasil penelitian

2 Dilengkapi dari hasil penelitian Linbald (1997)

3 Hazard rate didefinisikan sebagai rasio penganggur yang memperoleh pekerjaan pada bulan tertentu terhadap jumlah penganggur pada akhir bulan sebelumnya

4 Hipotesis ini didasari pemikiran bahwa human capital seseorang dapat berkurang selama orang tersebut menganggur dan akan semakin kuat jika masa menganggurnya semakin lama. 
menunjukan bahwa pengangguran jangka panjang bukan diakibatkan oleh penurunan human capital selama orang tersebut menganggur, melainkan lebih disebabkan oleh perbedaan usia dan jenis kelamin.

Arulampalam et al., (2000) melakukan penelitian mengenai status kebergantungan (state dependence) dari tingkat pengangguran di Inggris. Dengan menggunakan model panel data, mereka menemukan bahwa terdapat pengaruh status kebergantungan yang kuat dari pengangguran yang terjadi pada periode sebelumnya, khususnya untuk golongan pria dewasa. Penelitian ini juga menunjukkan bahwa kondisi pasar tenaga kerja lokal menghasilkan pengaruh yang kecil bagi para penganggur dengan kelompok usia muda. Para penganggur golongan usia muda bersifat independen terhadap pengaruh siklus bisnis. Usia, kesehatan, dan kualifikasi dari para tenaga kerja menjadi faktor-faktor penentu yang signifikan terhadap pengangguran.

Martin dan McCromick dalam Monastiriotis (2006) menemukan bahwa di Inggris terjadi fenomena persistensi pengangguran yang disebabkan oleh adanya perbedaan struktur lembaga dan ekonomi dalam kawasan regional. Adapun penyebab terjadinya fenomena ini adalah karakteristik struktural seperti sistem upah, technological and skill mismatches, demand

\begin{tabular}{|c|c|c|}
\hline \multicolumn{3}{|c|}{$\begin{array}{l}\text { Tabel III.1 } \\
\text { stensi Pengangguran secara Agregat }\end{array}$} \\
\hline Periode & Sumber-Sumber Persistensi Pengangguran & Penulis \\
\hline Tahun 1970-an & $\begin{array}{l}\text { Peran dari shock seperti kenaikan harga minyak dunia, slowdown } \\
\text { pertumbuhan produktivitas/euro-sclerosis (Real wage rigidities dan nominal } \\
\text { wage rigidities) }\end{array}$ & Bruno dan Sachs (1985) \\
\hline Tahun 1980-an & $\begin{array}{l}\text { Peran dari akumulasi kapital, peran insider, collective bargaining, inersia } \\
\text { dalam permintaan tenaga kerja, long term unemployment }\end{array}$ & $\begin{array}{l}\text { Alogoskoufis and Manning } \\
\text { (1988); } \\
\text { Blanchard and Summers } \\
\text { (1986); Kidd and Oswald } \\
\text { (1987); and Nickell and } \\
\text { Wadhwani (1990); Bean et al. } \\
\text { (1986); Grubb et al. (1982); } \\
\text { Newell and Symons (1985); } \\
\text { Lindbeck dan Snower (1986); } \\
\text { Barro (1988) }\end{array}$ \\
\hline Tahun 1990-an & $\begin{array}{l}\text { Peran dari institusi pasar tenaga kerja seperti proteksi tenaga kerja dan } \\
\text { asuransi pengangguran, tingginya arus keluar masuk tenaga kerja, } \\
\text { adjustment cost, pajak ketenagakerjaan, ketentuan upah minimum }\end{array}$ & $\begin{array}{l}\text { Pissarides (1990 dan 2000), } \\
\text { Phelps (1994), Nickel dan } \\
\text { layard (1998), Phelp dan Zoega } \\
\text { (1994), Feve (2002) }\end{array}$ \\
\hline Periode selanjutnya & $\begin{array}{l}\text { Peran dari shock lainnya, institusi lainnya, interaksi lainnya (regulasi pasar } \\
\text { produk, pemilikan rumah, turnover tenaga kerja yang tinggi, interest rate) }\end{array}$ & $\begin{array}{l}\text { Oswald (1997), Coe and } \\
\text { Snower (1997), Daveri dan } \\
\text { Tabellini (200), Bertola, } \\
\text { Rogerson (1997), Blanchard } \\
\text { dan Wolfers (2000), Cohen dan } \\
\text { Nouveau (2005) }\end{array}$ \\
\hline
\end{tabular}


Tabel III.2

Sumber Perbedaan Tingkat Persistensi Pengangguran berdasarkan Kriteria Tertentu

\begin{tabular}{|c|c|}
\hline Sumber Perbedaan Tingkat Persistensi Pengangguran Berdasarkan Regional & Penulis \\
\hline Tingginya share output sektor publik menyebabkan tingginya persistensi pengangguran di China & Wu, 2003 \\
\hline $\begin{array}{l}\text { Emerging wage flexibility, employment creation, labor mobility, housing market imperfections dan } \\
\text { asymmetric information menjadi faktor utama penyebab terjadinya perbedaan tingkat pengangguran } \\
\text { di negara-negara berkembang. }\end{array}$ & $\begin{array}{l}\text { Mc Cormick dan Shefpard, } \\
\text { 1992; } \\
\text { Bornhorst dan Commander, } \\
2004\end{array}$ \\
\hline $\begin{array}{l}\text { Industry mix, RGDP, labor taxes, shock to labor supply, regional differences in skill levels menjadi } \\
\text { penyebab utama tingginya penganguran di tingkat regional di Argentina. }\end{array}$ & Galiania, 2004 \\
\hline \multicolumn{2}{|l|}{ Sumber Perbedaan Tingkat Persistensi Pengangguran Berdasarkan Jenis Kelamin } \\
\hline $\begin{array}{l}\text { Penganguran pada jenis kelamin perempuan lebih persisten karena tingginya elastisitas upah dari } \\
\text { tenaga kerja wanita. }\end{array}$ & Murillo, 2005 \\
\hline \multicolumn{2}{|l|}{ Sumber Perbedaan Tingkat Persistensi Pengangguran Berdasarkan Umur } \\
\hline $\begin{array}{l}\text { Pengangguran pada usia }<25 \text { tahun dan }>45 \text { tahun lebih persisten yang disebabkan adanya } \\
\text { "scarring theory of unemployment." }\end{array}$ & Murillo, 2005 \\
\hline $\begin{array}{l}\text { "Scarring theory of unemployment" mendukung hasil penelitian tentang pengaruh pengalaman } \\
\text { menganggur masa muda terhadap tingkat pengangguran dewasanya }\end{array}$ & Greg, 2001 \\
\hline \multicolumn{2}{|l|}{ Sumber Perbedaan Tingkat Persistensi Pengangguran Berdasarkan Skilled vs Unskllied } \\
\hline $\begin{array}{l}\text { Penganguran pada angkatan kerja kelompok unskilled lebih tingi karena adanya kelompok skilled } \\
\text { labor yang bekerja untuk pekerjaan yang bersifat unskill }\end{array}$ & Collard, 2003 \\
\hline $\begin{array}{l}\text { Persistensi pengangguran pada kelompok tenaga kerja yang tidak tamat pendidikan formal di } \\
\text { Andalusia dan Extremadura Spanyol lebih tinggi karena masalah skill dari kelompok tersebut }\end{array}$ & Murillo, 2005 \\
\hline \multicolumn{2}{|l|}{ Sumber Perbedaan Tingkat Persistensi Pengangguran Berdasarkan Sektor } \\
\hline $\begin{array}{l}\text { Dengan menggunkanan pendekatan Bayesian ARFIMA, dapat ditunjukkan adanya perbedaan tingkat } \\
\text { persistensi pengangguran pada sektor-sektor perekonomian di Kanada. Hal ini terjadi karena } \\
\text { perbedaan daya serap dari masing-masing sektor dan teknologi yang dimilikinya. }\end{array}$ & Eberwein, et al 2002 \\
\hline
\end{tabular}

hysteresis, dan defisiensi penawaran tenaga kerja. Esensi terpenting dari penelitian ini menunjukkan bahwa fleksibilitas fungsi produksi justru terkait dengan tingginya pengangguran.

Wu (2003) melakukan penelitian yang menguji eksistensi persistensi pengangguran serta sumber persistensi yang terjadi di Cina. Studinya difokuskan pada perbedaan yang terjadi antara pengangguran total dan kaum muda (total dan youth unemployment), tingkat nasional dan regional dalam fenomena persistensi pengangguran di Cina. Hasil empiris menunjukkan tiga esensi penting. Pertama, pengangguran di tingkat provinsi (provincial unemployment) lebih persisten dibanding pengangguran agregat nasional (national aggregate unemployment). Kedua, pengangguran total lebih persisten daripada pengangguran kaum muda. Ketiga, walaupun wilayah barat Cina memiliki tingkat pengangguran provinsi tertinggi tetapi persistensi pengangguran regionalnya terendah. 
Berdasarkan teori dan studi empiris yang ada sebelumnya, maka penelusuran struktur pengangguran dan ketenagakerjaan di Indonesia dimulai dengan identifikasi persisten tidaknya pengangguran tersebut. Secara statistik, pembuktian keberadaan persistensi pengangguran dapat dilakukan dengan melihat karakterstik komponen trend dan siklikal dari data pengangguran. Lihat Grafik III.3.

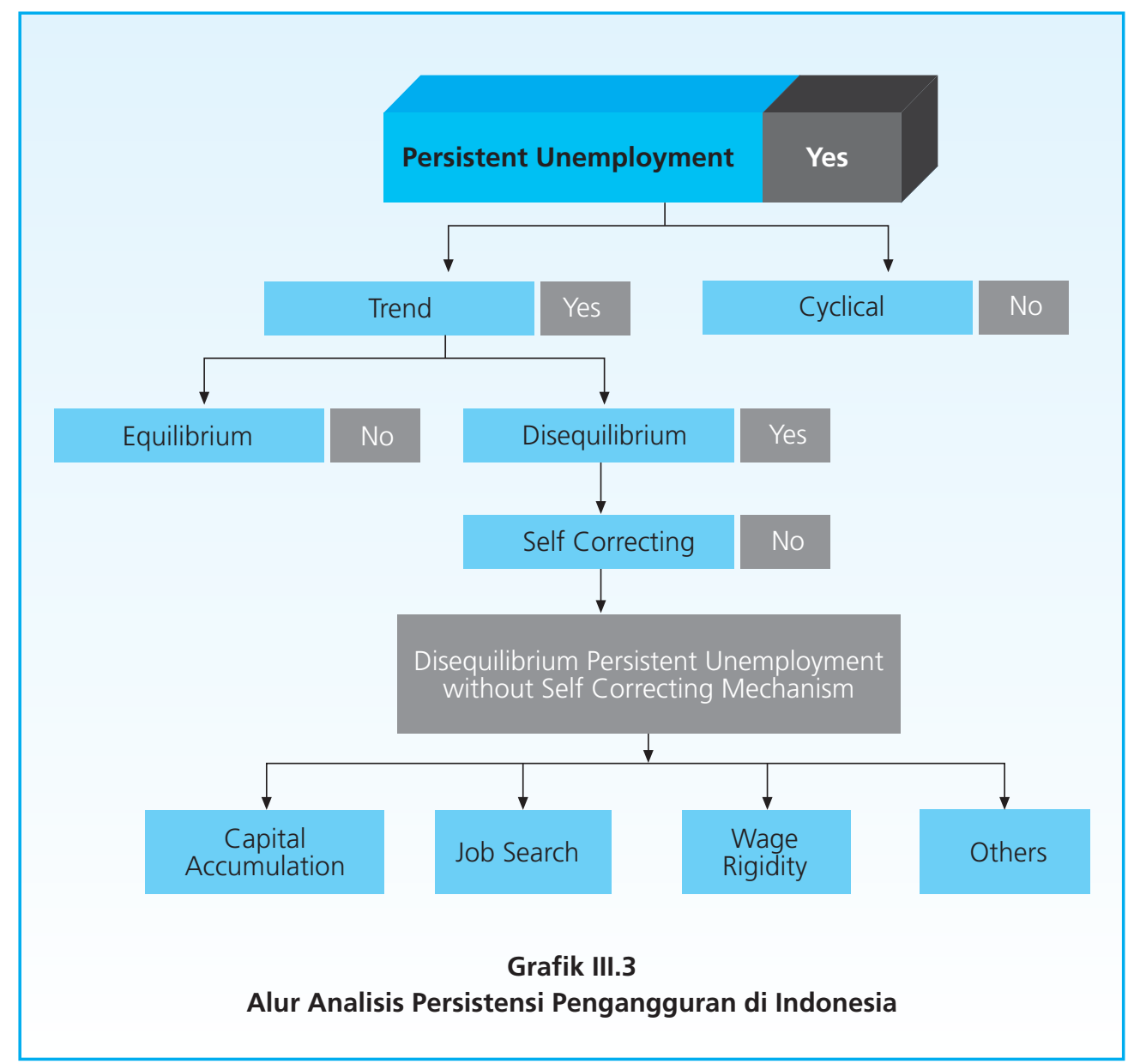

Sebuah fenomena persistensi pengangguran bisa terjadi di luar titik kesetimbangan. Hal ini dimungkinkan terjadi jika kekuatan pasar dan tata kelembagaan pasar tenaga kerja tidak lagi berfungsi seperti yang disyaratkan oleh teori neoklasik. Dalam teori ini, peningkatan pengangguran selalu dipandang sebagai peningkatan pengangguran alamiah dari waktu ke waktu yang disertai dengan tercapainya kesetimbangan pasar tenaga kerja. Artinya, pengangguran alamiah merupakan konsekuensi yang tidak terhindarkan dari market clearing 
mechanism. Untuk itu, penelusuran kedua terkait dengan (i) apakah tingkat dan dinamika pengangguran tersebut merupakan fenomena equilibrium atau justru disequilibrium, dan (ii) apakah terdapat mekanisme yang otomatis mampu mengoreksi dan mengembalikan kondisi tersebut ke tingkat keseimbangannya.

Penelusuran ketiga dilakukan untuk mengidentifikasi faktor-faktor apa saja yang mempengaruhi persistensi pengangguran tersebut. Berdasarkan teori dan berbagai studi empiris sebelumnya, faktor-faktor yang berpotensi mempengaruhi terjadinya persistensi pengangguran adalah mismatch antara permintaan dan penawaran tenaga kerja yang ada, lambatnya proses akumulasi modal, kekakuan upah, waktu pencarian lapangan kerja (job search), kemudahan perpindahan kerja lintas sector dan lintas wilayah, factor regulasi (ketentuan pesangon dan asuransi sosial), peran serikat pekerja, dan mekanisme penyesuaian serta faktor-faktor lain yang terkait dengan kelembagaan pasar tenaga kerja.

\section{METODOLOGI}

\section{III.1 Jenis dan Metode Pengumpulan Data}

Penelitian ini dilakukan dengan menggunakan data sekunder yang terkait dengan pengangguran selama kurun waktu 1991-2006 baik data agregat pada level nasional maupun regional per provinsi. Data ini dapat diperoleh dari Badan Pusat Statistik (BPS) dan berbagai dinas atau instansi terkait lainnya.

Penelitian ini juga menggunakan data primer yang diperoleh dari survei untuk memperoleh informasi mengenai kondisi pasar tenaga kerja. Survei ini melibatkan pelaku di pasar tenaga kerja yaitu pekerja, penganggur, pengusaha, serikat pekerja, dan instansi terkait dengan total responden 385 pihak. Untuk setiap provinsi yang terpilih sebagai wilayah survei, jumlah responden adalah sebagai berikut: perusahaan (15), instansi terkait (1), serikat pekerja (1), individu bekerja (30), dan individu pencari kerja atau penganggur (30).

Penentuan lokasi survei didasarkan pada keterwakilan provinsi-provinsi di kawasan barat dan timur Indonesia dan tingkat kecenderungan pengangguran di setiap pulau selama tahun 1996-2006. Berdasarkan kriteria tersebut, maka provinsi-provinsi yang menjadi wilayah survei adalah: Riau, Jawa Barat, Kalimantan Barat, Sulawesi Utara, dan Nusa Tenggara Barat (NTB). Dari setiap propinsi ini, ditentukan dua kota atau kabupaten yang representatif dengan kriteria: (1) kota atau kabupaten dengan PDRB per kapita mendekati PDRB per kapita provinsi, dan (2) kota atau kabupaten yang memiliki tingkat pengangguran tertinggi. Dengan merujuk pada kriteria tersebut, penelitian dilakukan di wilayah berikut: 
1. Riau (Kabupaten Pelalawan dan Kota Pekanbaru),

2. Jawa Barat (Kabupaten Bogor dan Kota Cimahi),

3. Kalimantan Barat (Kota Pontianak dan Kabupaten Pontianak),

4. Sulawesi Utara (Kota Manado dan Kabupaten Bolaang Mongondow),

5. Nusa Tenggara Barat (Kota Mataram dan Kabupaten Lombok Timur).

\section{III.3 Teknik Analisis}

Penelitian ini menerapkan metode kuantitatif. Selain analisis deskriptif dalam bentuk grafik, tabel dan cross-tabulation, Penelitian ini juga melakukan pengujian inferensial untuk menjawab pertanyaan penelitian yang diangkat. Langkah pertama adalah identifikasi awal tingkat persistensi pengangguran dan apakah pengangguran tersebut merupakan pengangguran alamiah atau tidak. Merujuk studi yang dilakukan Elmeskov (1993), pengujian ini dapat dilakukan dengan uji stasioneritas dengan alternatif pendekatan: (1) unit root dengan konstanta, (2) unit root dengan drift, dan (3) unit root dengan drift dan trend.

Misalkan variabel time series untuk data pengangguran $(u)$ adalah sebagai berikut,

$$
u_{t}=\alpha+\phi_{i} u_{\mathrm{t}-1}+e_{i, t}
$$

di mana $\phi$ adalah parameter yang akan diestimasi dan e diasumsikan white noise. Jika $|\phi| \geq 1$, maka $u_{t}$ adalah variabel yang tidak stasioner atau dalam definisi Blanchard dan Summers (1986), terjadi pengangguran yang histeris, sehingga terdapat efek fluktuasi yang permanen. Jika $|\phi|<1$, maka $u_{i}$ adalah variabel yang stasioner atau trend-stationarity atau dengan kata lain terjadi pengangguran yang alamiah.

Lebih lanjut, pengangguran yang persisten terjadi jika nilai $\phi$ mendekati nilai 1. Karena itu, hipotesis trend-stationarity dapat dievaluasi dengan menguji apakah nilai absolut dari $\rho$ betul-betul lebih kecil dari 1. Pengujian umum terhadap hipotesis di atas adalah $\mathrm{HO}: \phi=1$, dengan pengujian satu sisi dari hipotesis alternatif $\mathrm{H} 1: \phi<1$.

Standar umum pengujian akar-akar unit dari Dickey-Fuller (DF) adalah persamaan (3.1). Kemudian, dengan mengurangi kedua sisi persamaan (III.1) dengan $u_{t-1,}$ diperoleh persamaan:

$$
\Delta u_{t}=\rho u_{t-1}+\varepsilon_{t}
$$

atau dengan menambahkan variabel lag $\Delta u_{t}$ di sisi kanan persamaan (III.2) akan diperoleh pengujian Augmented Dickey-Fuller (ADF) sebagai berikut: 


$$
\Delta u_{t}=\rho u_{t-1}+\sum_{t=1}^{j} \gamma_{j} \Delta u_{t-j}+\varepsilon_{t}
$$

Di mana $\Delta$ mengindikasikan perbedaan pertama (first difference), sedangkan $r=(\phi-1)$, sehingga hipotesis nol menjadi $\mathrm{HO}: \rho=0$, sedangkan hipotesis alternatif menjadi $\mathrm{H} 1: \rho<0$. Pengujian terhadap hipotesis ini dapat dievaluasi dengan t-statistik biasa, yang kemudian dikembangkan oleh Dickey-Fuller (1979) karena mereka menunjukkan bahwa dalam hipotesis nol adanya akar-akar unit, $t$-statistics yang diperoleh tidak mengikuti student's t-distribution'yang konvensional. Pada saat ini tabulasi yang sering digunakan adalah tabulasi dari Mackinnon (1991, 1996).

Dalam studi ini digunakan tiga indikator untuk mengukur trend pengangguran yaitu indikator NAWRU, kurva Beveridge dan kurva Okun. NAWRU (Non Accelerating Wage Rate of Unemployment) menunjukkan besarnya tingkat pengangguran yang dapat mengakselerasi kenaikan upah. Indikator NAWRU diperoleh dengan formula:

$$
N A W R U=U-\left(D U / D^{2} \log W\right) * D \log W
$$

di mana:

$$
\begin{aligned}
& U=\text { tingkat pengangguran aktual, } \\
& W=\text { upah nominal, } \\
& D=\text { first difference operator. }
\end{aligned}
$$

Kurva Beveridge adalah kurva yang menggambarkan hubungan antara tingkat pengangguran dengan lowongan kerja (vacancy rate). Indikator kurva Beveridge diperoleh dengan formula:

$$
\mathrm{b}=\mathrm{U}^{*} \mathrm{~V}^{\operatorname{med}(-\mathrm{D} \log \mathrm{U} / \mathrm{Dlog} \mathrm{V})}
$$

di mana:

$$
\begin{aligned}
& \mathrm{U}=\text { tingkat pengangguran aktual, } \\
& \mathrm{V}=\text { vacancy rate. }
\end{aligned}
$$

Kurva Okun adalah kurva yang menggambarkan hubungan antara tingkat pengangguran dengan output. Indikator kurva Okun diperoleh dengan menggunakan metode yang relatif sama dengan formula untuk membangun indikator NAWRU, dengan mengganti inflasi upah dengan utilisasi kapasitas (capacity utilization).

Pengujian inferensial factor-faktor yang mempengaruhi struktur dan dinamika pengangguran di Indonesia dilakukan dengan teknik estimasi data panel. Teknik ini berbeda dari regresi time-series atau regresi cross-section karena dalam regresi data panel setiap variabel mengandung subscript ganda it. Rumusan umum untuk regresi data panel dapat dirumuskan: 


$$
y_{i t}=\alpha+\beta x_{i t}^{\prime}+u_{i t} \quad i=1, \ldots, N ; t=1, \ldots, T
$$

dengan $i$ menunjukkan unit tertentu seperti rumah tangga, individu,perusahaan, propinsi, negara dan sebagainya sedangkan $t$ menunjukkan waktu. Oleh karena itu, menandakan dimensi cross-section dan $t$ menandakan dimensi waktu. $\alpha$ adalah intersep, $\beta$ adalah slope, dan $x_{i t}$ merupakan explanatory variables pada pengamatan it. Umumnya penerapan data panel menggunakan model one-way error component dalam bentuk:

$$
u_{i t}=\mu_{i}+v_{i t}
$$

di mana $\mu_{i}$ menunjukan pengaruh spesifik individu yang tidak dapat diamati dan $v_{i t}$ adalah sisaan (disturbance). Dalam analisa model data panel dikenal tiga macam pendekatan yang terdiri atas pendekatan kuadrat terkecil (pooled least square), pendekatan efek tetap (fixed effect), dan pendekatan efek acak (random effect).

\section{HASIL DAN ANALISIS}

\section{IV.1 Deskripsi Ketenagakerjaan Indonesia}

Tingkat pengangguran di Indonesia cenderung terus mengalami peningkatan. Selang periode 1996-2000, tingkat pengangguran rata-rata tercatat sebesar 5,49 persen, yang kemudian selang periode 2000-2006 meningkat menjadi 9,57 persen. Fenomena meningkatnya pengangguran tersebut seiring dengan peningkatan jumlah angkatan kerja, (Grafik III.4).

Sejak tahun 1996 pengangguran usia muda di Indonesia berjumlah sekitar dua kali lebih besar dibandingkan pengangguran usia dewasa ${ }^{5}$ (Grafik III.5). Fenomena dominannya proporsi penganggur muda dibandingkan penganggur usia tua dikenal dengan fenomena down skilling ${ }^{6}$.

Salah satu faktor yang ditengarai menjadi penyebab tingginya pengangguran usia muda adalah lemahnya sistem pendidikan dalam mempersiapkan siswanya untuk memasuki dunia kerja. Sistem pendidikan yang terbangun selama ini tampaknya masih menghasilkan angkatan kerja usia muda dengan kemampuan yang terbatas (lack of skill) dan kurang pengalaman (lack of experience).

Dari total penganggur, 90\% diantaranya merupakan angkatan kerja yang bersifat unskilled. Berdasarkan gender, tingkat pengangguran laki-laki lebih tinggi dibandingkan

\footnotetext{
5 Pola ini juga banyak ditemui di negara-negara Eropa (Blanchard, 2005)

6 Down skilling didefinisikan adanya tenaga kerja dengan keahlian dan pendidikan yang lebih tinggi (skilled) yang bekerja untuk pekerjaan yang bersifat unskilled (Collard, 2003).
} 
pengangguran wanita7 meski terdapat kecenderungan bahwa perbedaan tingkat pengangguran antargender tersebut semakin mengecil. Lihat grafik berikut.
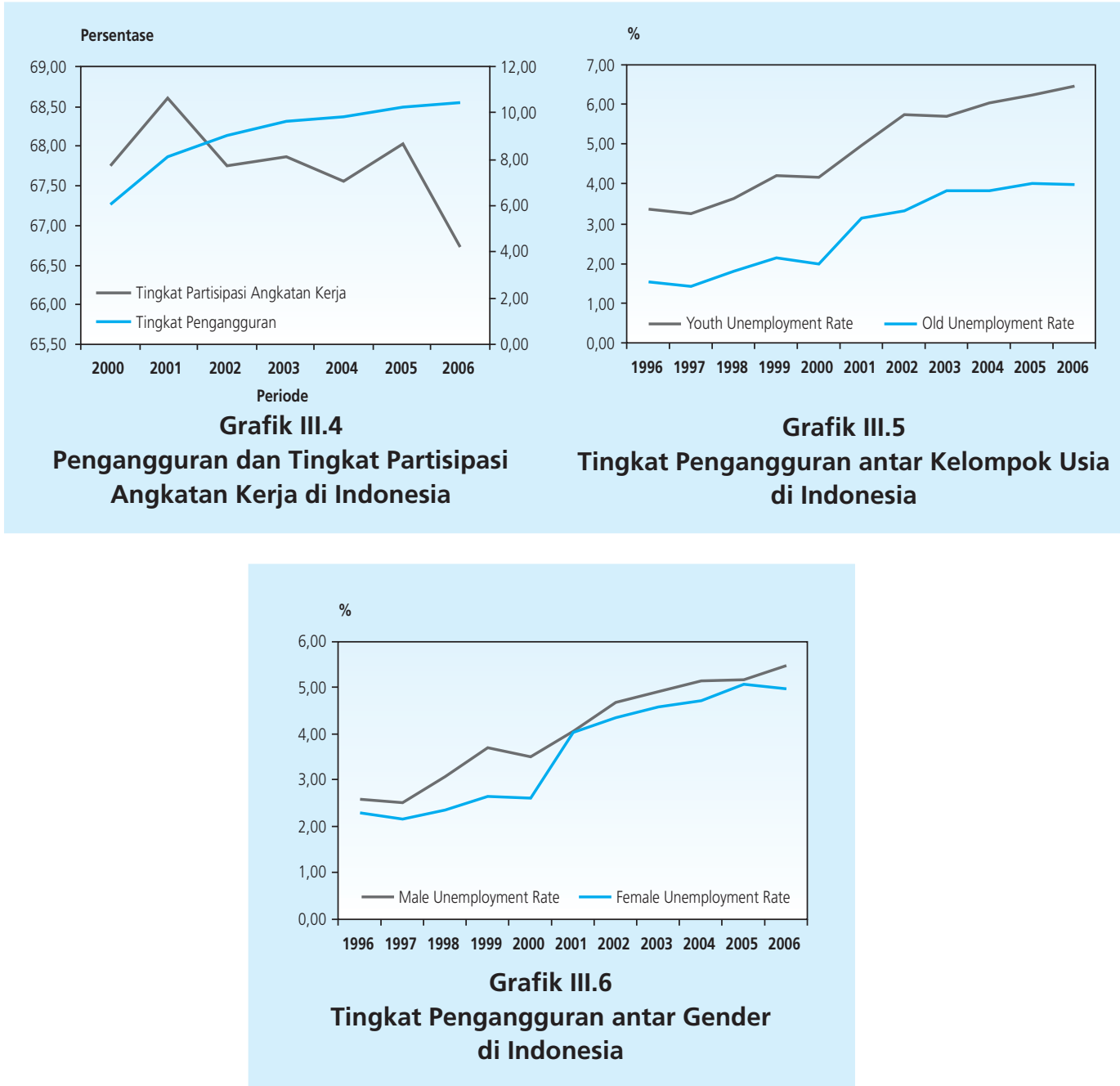

Pasar tenaga kerja Indonesia dicirikan dengan sebagian kecil pekerja bekerja di sektor formal dan mayoritas pekerja hanya dapat tertampung di sektor informal atau dapat dikatakan bersifat dualistik (Grafik III.7). Selain itu, semenjak 2004 struktur tenaga kerja menurut tipe pekerjaan relatif tetap dimana tenaga kerja yang memiliki profesi sebagai pekerja/karyawan/ buruh yang dibayar jumlahnya relatif konstan (Grafik III.8). Hal ini menunjukkan bahwa kemampuan perusahaan dalam menyerap tenaga kerja sebagai karyawan/pekerja juga relatif

7 Hal ini berbeda dengan studi Murillo (2005) yang menemukan bahwa tingkat pengangguran wanita lebih persisten dibanding pria. Sementara studi Elmeskov (2003) menunjukkan kondisi yang sama dengan Indonesia juga dialami oleh beberapa negara di Eropa, namun sebagian lainnya memiliki tingkat pengangguran wanita yang lebih tinggi dibanding tingkat pengangguran laki-lakinya. 


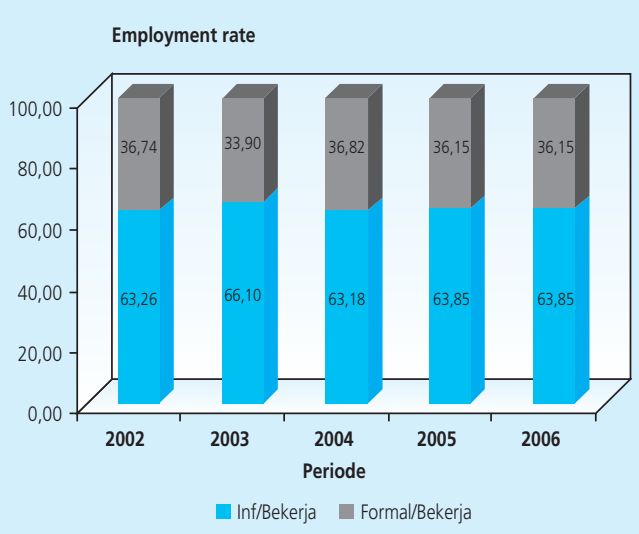

Grafik III.7

Struktur Tenaga Kerja Menurut Kegiatan Formal-Informal

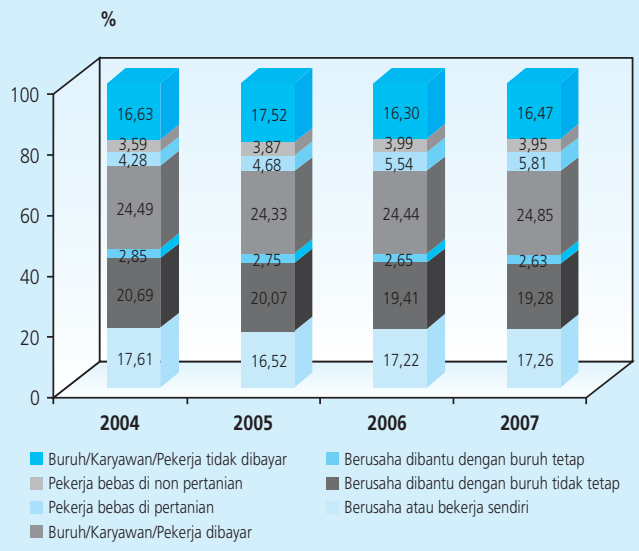

Grafik III.8

Struktur Tenaga Kerja Menurut Jenis Pekerjaan

tidak ada perubahan. Dengan demikian diperlukan perubahan paradigma pendidikan, para siswa harus disiapkan untuk menjadi enterpreneur pencipta lapangan pekerjaan daripada hanya sekedar pencari kerja.

Berdasarkan sebaran spasial, tingkat pengangguran lintas provinsi memiliki heterogenitas yang tinggi (Grafik III.9). Dari 33 provinsi, 14 provinsi diantaranya memiliki tingkat pengangguran melebihi tingkat pengangguran nasional. Provinsi dengan tingkat pengangguran tertinggi adalah Kepulauan Riau (16,34 persen) sedangkan yang terendah adalah Papua (4,50 persen).

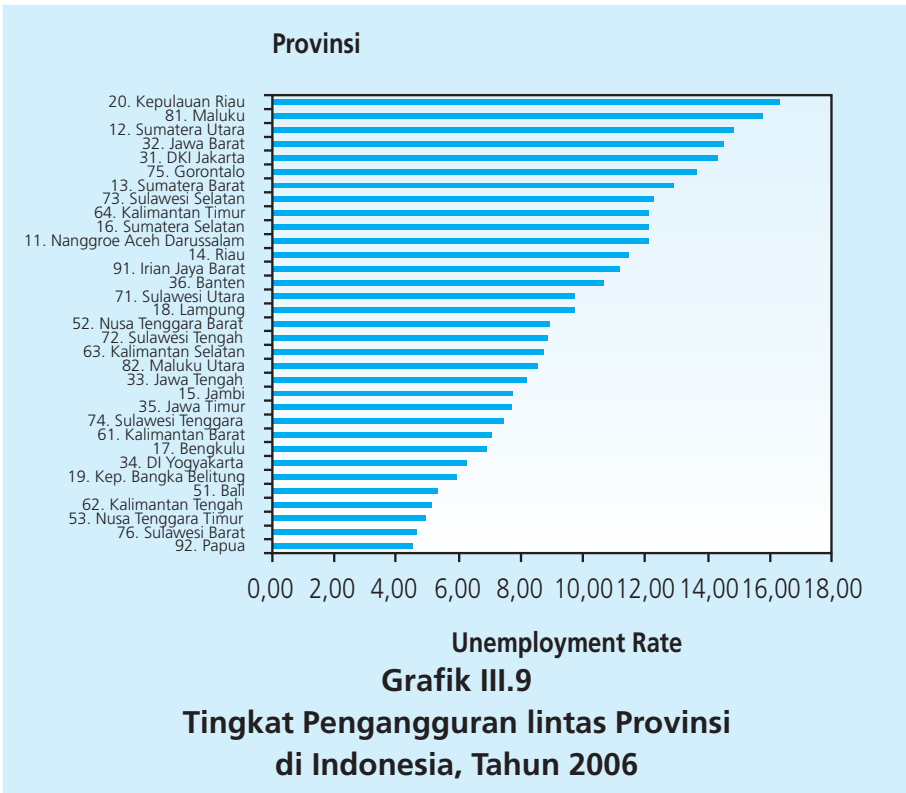


Table III.3

Tingkat Pengangguran Regional di Indonesia

Tahun

(Jumlah Provinsi)

$1996(26)$

$2000(25)$

$2006(33)$
Quartile wilayah Quartile wilayah dengan UE rate dengan UE rate terendah

3,43

3,68

7,06 tertinggi

\section{Jarak antar} Quartile

5,84

5,92

12,11
2,41

2,24

5,05
Rata-rata Terbobot

4,76

5,31

9,72

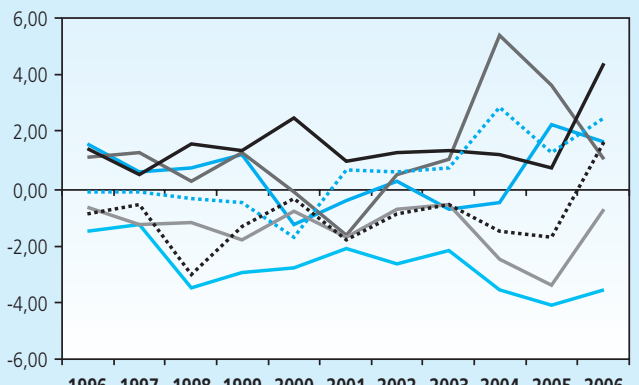

19961997199819992000200120022003200420052006

\begin{tabular}{|c|c|c|}
\hline $\begin{array}{l}\text { 11. Nanggroe Aceh Darussalam } \\
\text { 14. Riau }\end{array}$ & $\begin{array}{l}\text { 12. Sumatera Utara } \\
\text { 15. Jambi }\end{array}$ & $\begin{array}{l}\cdots \cdots 13 \text {. Sumatera Barat } \\
\cdots \cdots \text { 16. Sumatera Selatan }\end{array}$ \\
\hline-17 & 18. Lampung & \\
\hline
\end{tabular}

Grafik III.10

Selisih Tingkat Pengangguran Provinsi dengan Nasional di Pulau Sumatera

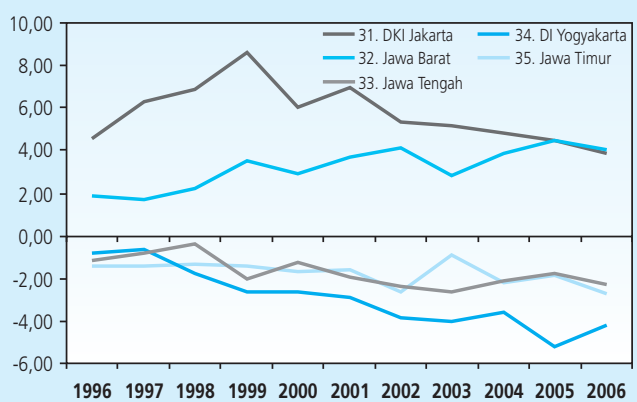

Grafik III.11

Selisih Tingkat Pengangguran Provinsi dengan Nasional di Pulau Jawa

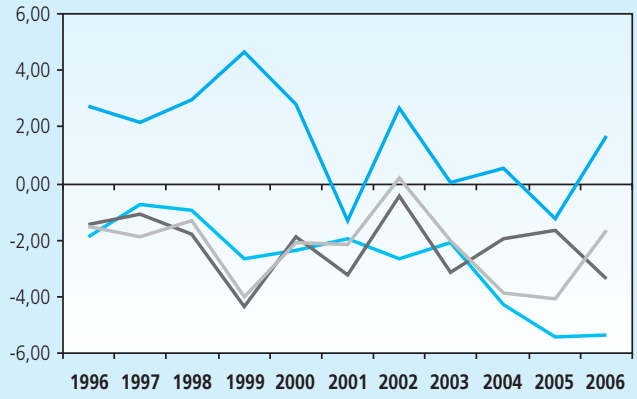

-61. Kalimantan Barat $\quad-62$. Kalimantan Tengah

63. Kalimantan Selatan $\quad$ 64. Kalimantan Timur

Grafik III.12

Selisih Tingkat Pengangguran Provinsi dengan Nasional di Pulau Kalimantan

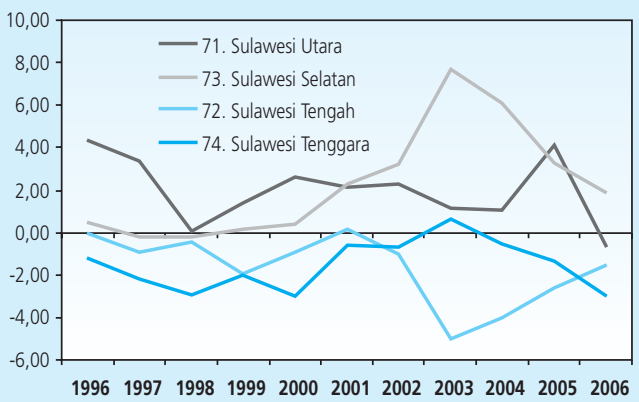

Grafik III.13

Selisih Tingkat Pengangguran Provinsi dengan Nasional di Pulau Sulawesi 


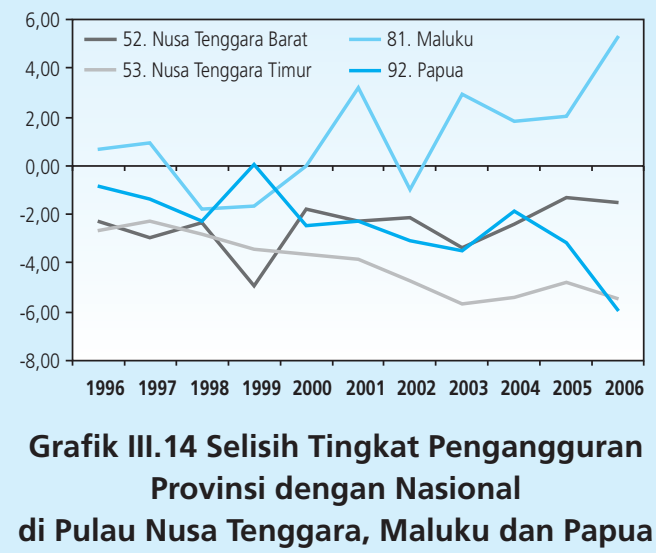

Perbedaan tingkat pengangguran antar wilayah ini cenderung meningkat dan bersifat konvergen, (Grafik III.10 - 14 dan - Tabel III.3). Pada tahun 1996 dengan 26 provinsi, tingkat pengangguran terendah dan tertinggi adalah sebesar 3,43 persen dan 5,84 persen, pada tahun 2006 dengan 33 provinsi masing-masing meningkat menjadi 7.06 persen dan 12.11 persen. Ini menunjukkan jarak antar kuartil tingkat pengangguran lintas daerah semakin besar dan membawa konsekuensi baik terhadap tingkat pengangguran agregat maupun divergensi lintas provinsi di Indonesia.

Bukti empirik menunjukkan adanya ketimpangan penyerapan tenaga kerja antar wilayah di Indonesia (Grafik III.15) Hal ini menunjukkan bahwa proses pembangunan antar wilayah relatif tidak merata. Selain itu, tenaga kerja lebih banyak terserap di pedesaan dibanding perkotaan (Grafik III.16). Hal ini terkait erat dengan sektor pertanian yang umumnya berada di

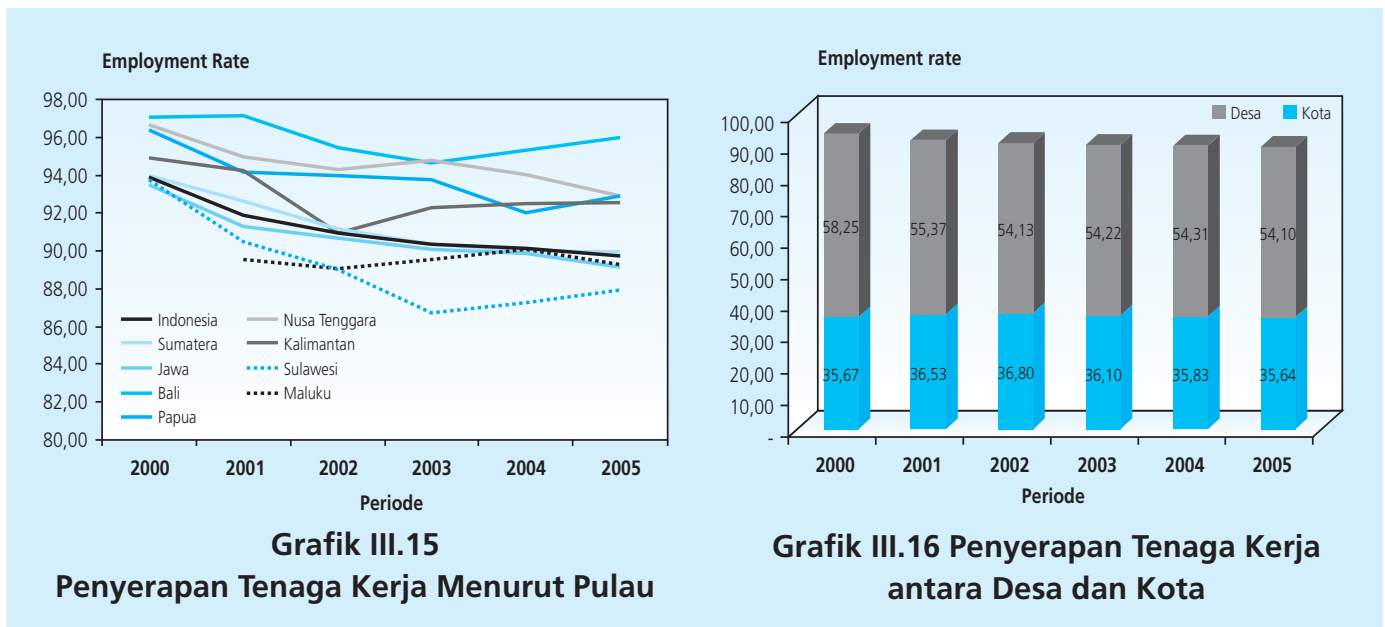


pedesaan. Kedua kondisi ini mengindikasikan bahwa pembangunan pedesaan dan pertanian diharapkan mampu mengurangi pengangguran, namun perlu diperhatikan bahwa pembangunan di sektor dan wilayah tersebut juga memerlukan sumberdaya manusia yang berkualitas, produktif dan profesional.

Dalam era otonomi daerah, salah satu tujuan pemekaran adalah upaya penciptaan dan perluasan lapangan pekerjaan dan pencapaian pertumbuhan yang lebih merata. Namun demikian, tampaknya pemekaran dan otonomi daerah belum secara efektif menjadi solusi masalah pengangguran.

Peningkatan dispersi tingkat pengangguran lintas daerah juga terlihat dari nilai standar deviasi yang cenderung terus meningkat (Tabel III.4). Salah satu faktor yang diduga mendorong terjadinya perbedaan tingkat pengangguran antar daerah yang cukup besar adalah adanya hambatan mobilitas tenaga kerja antar daerah. Namun, apabila ukuran dispersi dilihat dari coefficient of variation $(\mathrm{CV})^{8}$, pengangguran agregat meningkat relatif besar sehingga ukuran dispersi yang dinormalisasi cenderung menurun.

\begin{tabular}{|c|c|c|c|}
\hline \multicolumn{4}{|c|}{$\begin{array}{c}\text { Table III.4 } \\
\text { Ukuran Dispersi Pengangguran Regional }\end{array}$} \\
\hline $\begin{array}{l}\text { Tahun } \\
\text { (Jumlah Provinsi) }\end{array}$ & $\begin{array}{c}\text { Coefficient of Variation } \\
\text { Tingkat Pengangguran } \\
\text { Regional }\end{array}$ & $\begin{array}{l}\text { Standard deviasi Tingkat } \\
\text { Pengangguran Regional }\end{array}$ & $\begin{array}{c}\text { Tingkat Pengangguran } \\
\text { Nasional }\end{array}$ \\
\hline $\begin{array}{l}1996(26) \\
2000(25) \\
2006(33)\end{array}$ & $\begin{array}{l}0,404 \\
0,448 \\
0,355\end{array}$ & $\begin{array}{l}1,924 \\
2,38 \\
3,455\end{array}$ & $\begin{array}{c}4,86 \\
6,08 \\
10,45\end{array}$ \\
\hline
\end{tabular}

\section{IV.2 Hasil Estimasi Model}

\section{IV.2.1. Pengujian Persistensi Pengangguran}

Mengacu pada teori yang telah dijelaskan sebelumnya, pembuktian keberadaan persistensi pengangguran di Indonesia dilakukan dengan dua pendekatan yakni: pendekatan ekonometrika dan pendekatan grafis dengan membandingkan tren alamiah pengangguran (Kurva NAWRU, Kurva Beveridge, dan Kurva Okun).

Hasil pengujian menunjukkan bahwa data tingkat pengangguran mengikuti pola autoregressive yang mendekati unit root dengan koefisien persistensi 0,934 (Tabel III.5). Fakta ini kemudian didukung dari grafik tren pengangguran alamiah yang semakin naik (Grafik III. 17). Artinya, secara statistika tingkat pengangguran cenderung konvergen ke nilai jangka panjangya

8 Pada pendekatan ini tingkat pengangguran dinormalisasi untuk mengakomodasi peningkatan pengangguran secara umum 


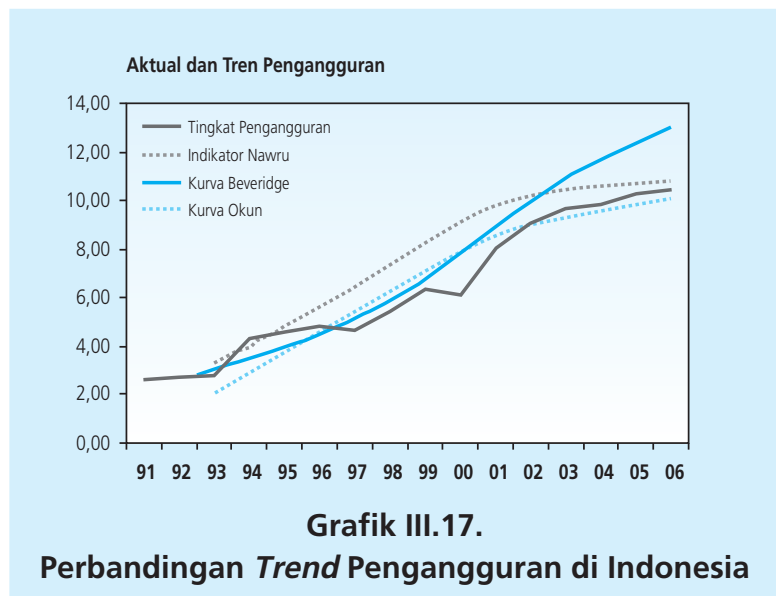

\begin{tabular}{|c|c|c|c|c|}
\hline \multicolumn{5}{|c|}{$\begin{array}{c}\text { Table III.5 } \\
\text { Pengujian Persistensi Pengangguran di Indonesia }\end{array}$} \\
\hline \multicolumn{3}{|c|}{$\begin{array}{l}\text { Probability of unit root against } \\
\text { hypothesis of stationarity with: }\end{array}$} & \multirow{2}{*}{$\begin{array}{l}\text { Persistence } \\
\text { (coefficient AR) }\end{array}$} & \multirow{2}{*}{$\begin{array}{l}\text { Standard } \\
\text { Deviation }\end{array}$} \\
\hline Constancy & Drift & Drift and Trend & & \\
\hline 0,955 & 0,493 & 0,0001 & 0,934 & 0,068 \\
\hline
\end{tabular}

tetapi dengan kecepatan yang sangat lambat. Dengan demikian, periode high unemployment dapat berlangsung dalam jangka waktu yang sangat lama.

Untuk melihat perbandingan persistensi pengangguran nasional dan regional kami menggunakan pendekatan regresi. Beberapa hasil temuan penting adalah: (1) Persistensi pengangguran terjadi baik di level provinsi maupun nasional, terlihat dari nilai koefisien yang signifikan; (2) Pengangguran di tingkat nasional lebih persisten dibandingkan dengan tingkat regional baik pada model yang menggunakan variabel dummy maupun yang tidak menggunakan variabel dummy tahun; (3) Pengangguran di Kawasan Indonesia Barat lebih persisten dibandingkan dengan Kawasan Indonesia Timur9 (Tabel III.6.a dan III.6.b).

Tingginya persistensi pengangguran di kawasan barat Indonesia disebabkan oleh perbedaan laju pertumbuhan antara angkatan kerja dengan ketersediaan lapangan kerja (Tabel III.7) dan adanya hambatan mobilitas tenaga kerja antar daerah. Angkatan kerja di kawasan barat Indonesia sejak tahun 2000 hingga tahun 2005 rata-rata meningkat sebesar 1.81 persen sementara ketersediaan lapangan kerja cenderung menurun.

9 Kawasan Barat diwakili Jawa, Sumatera, dan Bali. Sementara untuk kawasan Timur Indonesia diwakili oleh Kalimantan, Sulawesi, Irian Jaya, Nusa Tenggara Timur, Nusa Tenggara Barat dan Maluku. 


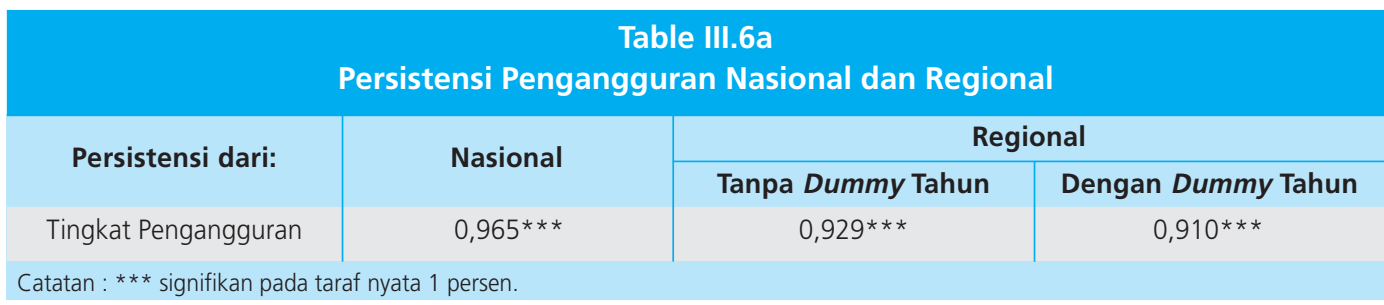

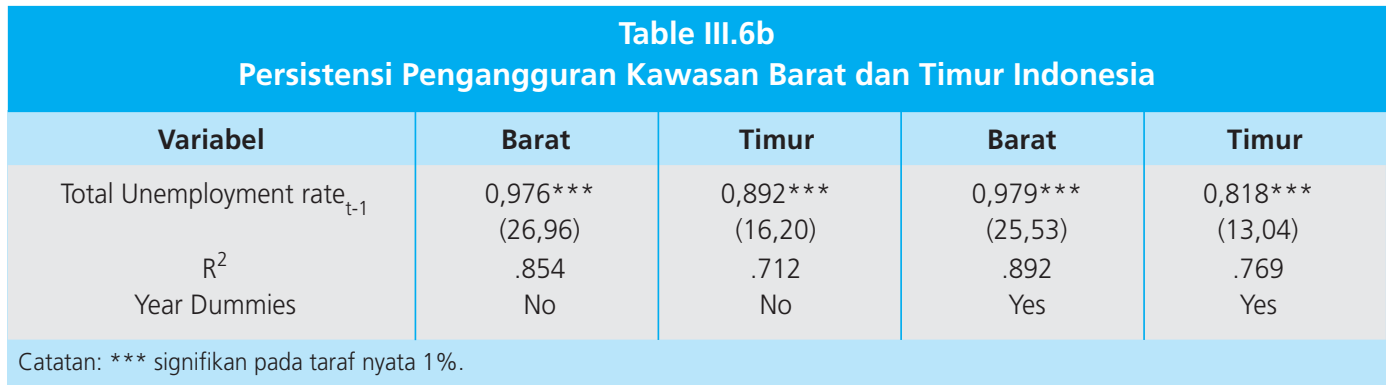

\begin{tabular}{|c|c|c|c|c|}
\hline \multirow{4}{*}{ Periode } & umbuhan Angk & $\begin{array}{l}\text { ble III.7 } \\
\text { tan Kerja dan L }\end{array}$ & oangan Kerja & \\
\hline & \multicolumn{4}{|c|}{ Pertumbuhan } \\
\hline & \multicolumn{2}{|c|}{ Angkatan Kerja } & \multicolumn{2}{|c|}{ Job Vacancy } \\
\hline & Indonesia Barat & Indonesia Timur & Indonesia Barat & Indonesia Timur \\
\hline $\begin{array}{c}2000 \\
2001 \\
2002 \\
2003 \\
2004 \\
2005 \\
\text { Rata-rata }\end{array}$ & $\begin{array}{l}2,02 \\
2,56 \\
1,33 \\
1,59 \\
1,52 \\
1,84 \\
1,81\end{array}$ & $\begin{array}{c}-4,52 \\
6,96 \\
5,10 \\
3,59 \\
-0,27 \\
1,40 \\
2,04\end{array}$ & $\begin{array}{c}-9,48 \\
-77,88 \\
4,46 \\
-45,98 \\
25,14 \\
70,52 \\
-5,54\end{array}$ & $\begin{array}{c}-41,75 \\
-55,46 \\
-40,62 \\
363,59 \\
-51,64 \\
50,29 \\
37,40\end{array}$ \\
\hline
\end{tabular}

\section{IV.2.2. Identifikasi Fenomena Equilibrium dan Self Correcting Mechanism}

Permasalahan dapat menjadi kompleks ketika kondisi persistensi pengangguran tersebut merupakan kondisi disequilibrium. Dalam kondisi ini ketika terdapat berbagai guncangan, maka terlalu sulit untuk bisa kembali ke titik kesetimbangan semula sehingga titik konvergensi tidak akan pernah tercapai.

Untuk bisa menduga apakah terdapat kecenderungan bahwa pengangguran pada akhirnya akan konvergen kepada sebuah titik atau tidak maka harus diidentifikasi setidaknya dua komponen yaitu tren (trend) dan siklikal (cyclical). Kalau ternyata komponen tren-nya jauh lebih dominan maka pengangguran akan cenderung mengalami peningkatan dalam jangka waktu yang lama. 
Trend pengangguran didefinisikan sebagai perubahan dalam tingkat pengangguran alamiah. Pengukuran tren dalam penelitian ini menggunakan tiga konsep pengangguran alamiah yaitu NAWRU, kurva Beveridge, dan kurva Okun. Ketiga ukuran ini secara konsisten menunjukan bahwa tingkat pengangguran alamiah di Indonesia cenderung mengalami peningkatan terutama setelah krisis. Dengan demikian ada bukti kuat bahwa persistensi pengangguran disebabkan oleh peningkatan tren dan bukan variasi siklis.

Hasil estimasi menunjukkan komponen tren mendominasi komponen siklikal. Ini terlihat dari variabilitas output yang tinggi sebesar 2.448 hanya bisa dijelaskan oleh variabilitas tenaga kerja sebesar 0,669. Lebih lanjut, elastisitas partisipasi tenaga kerja terhadap output hanya 0.387 (Tabel III.8). Dengan kata lain, respon partisipasi tenaga kerja terhadap output yang bersifat siklis, relative terlalu kecil untuk bisa menjelaskan keberadaan persistensi pengangguran yang telah dibuktikan sebelumnya.

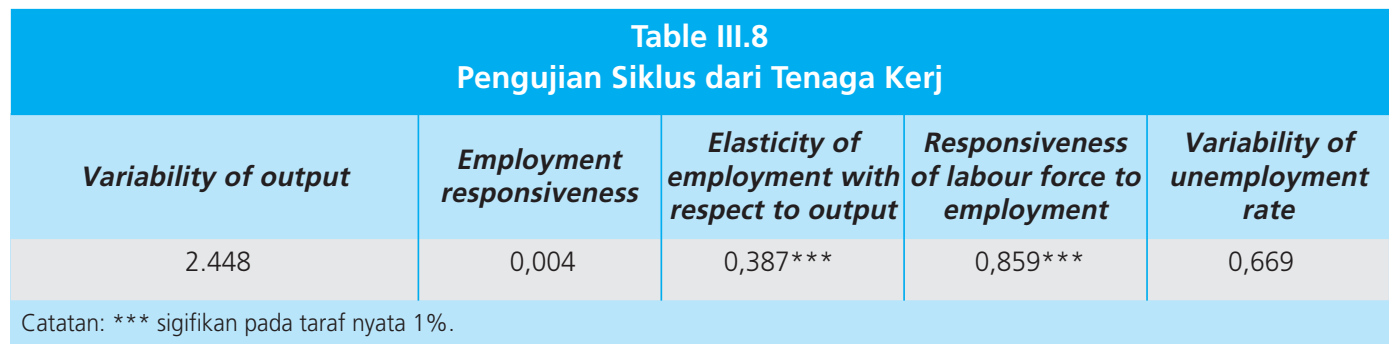

Sampai titik ini, ada beberapa implikasi penting dari temuan di atas. Pertama, peningkatan pengangguran yang terjadi selama ini kecil kemungkinannya merupakan akibat dari rendahnya tingkat pertumbuhan. Oleh karena itu perbaikan dalam tingkat pertumbuhan menjadi tidak cukup untuk mengatasi masalah pengangguran. Kedua, karena terjadi peningkatan trend unemployment, maka terdapat kecendrungan yang kuat bahwa pengangguran alamiah di Indonesia telah mengalami peningkatan dari waktu ke waktu.

Kedua poin tersebut berlmplikasi pada pemecahan masalah pengangguran alamiah yang kemungkinan besar berakar pada fundamental ekonomi Indonesia. Karena masalahnya berada pada fundamental ekonomi Indonesia maka yang menjadi pertanyaan kemudian adalah, apakah di dalam fundamental tersebut terdapat mekanisme yang secara automatis dapat mengoreksi dan mengembalikan kondisi menuju keseimbangan (self correcting mechanism)?

Untuk menjawab pertanyaan tersebut, terlebih dahulu harus dibuktikan apakah trend pengangguran merupakan fenomena equilibrium atau disequilibrium. Jika merupakan fenomena equilibrium maka pengangguran yang persisten merupakan konsekuensi dari pengangguran alamiah. Peningkatan pengangguran alamiah yang tidak disertai dengan market clearing 
merupakan penggangguran yang sulit untuk ditekan karena merupakan fenomena pergeseran kesetimbangan jangka panjang.

Secara teknis, peningkatan trend pengangguran dalam kondisi equilibrium ditandai oleh negatifnya reaksi upah (nominal atau riil) terhadap dan hanya terhadap deviasi tingkat pengangguran dari trend-nya. Hasil estimasi menunjukkan hal yang sebaliknya dimana koefisien $g$ justru menujukkan pengaruh deviasi pengangguran (dari trend-nya) yang bernilai positif terhadap pembentukan upah, (Tabel III.9). Pengujian ini menunjukan bahwa tidak terdapat perubahan tingkat pengangguran alamiah jangka panjang di Indonesia.

Karena bukan merupakan fenomena equilibrium maka alternatif hipotesisnya adalah bahwa persistensi disebabkan oleh histerisis yakni pengangguran cenderung meningkat secara persisten tapi kemudian secara perlahan kembali ke kesetimbangan jangka panjang (slow adjustment).

\begin{tabular}{|c|c|c|c|c|}
\hline \multicolumn{5}{|c|}{$\begin{array}{l}\text { Table III.9 } \\
\text { enaga Kerja Pada Pembentukan Upah }\end{array}$} \\
\hline Persamaan & Koefisien & Nilai & Signifikansi & $\mathbf{R}^{2}$ \\
\hline $\begin{array}{l}(1) \\
(2) \\
(3)\end{array}$ & $\begin{array}{l}d \\
g \\
d \\
g \\
d \\
e \\
d \\
e\end{array}$ & $\begin{array}{r}-0.048 \\
0.065 \\
-0.007 \\
0.024 \\
-0.021 \\
0.022 \\
0.0003 \\
-0.001\end{array}$ & $\begin{array}{c}* * * \\
\star * * \\
\text { tidak signifikan } \\
\star * \star \\
\star * \star \\
* * * \\
\text { tidak signifikan } \\
\text { tidak signifikan }\end{array}$ & $\begin{array}{l}0.686 \\
0.704 \\
0.699 \\
0.816\end{array}$ \\
\hline \multicolumn{5}{|c|}{ 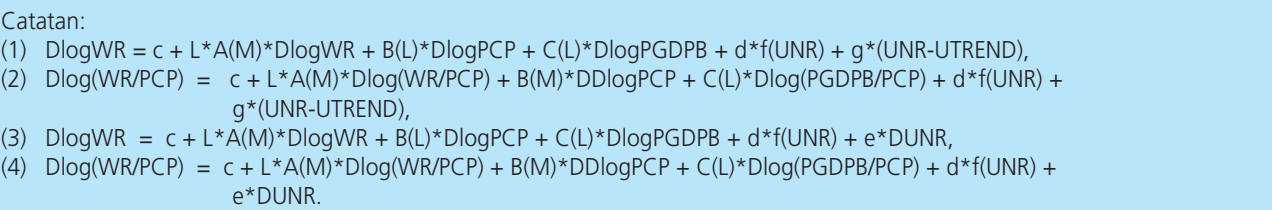 } \\
\hline
\end{tabular}

Lebih lanjut, hasil estimasi pada Tabel III.9 tersebut menunjukkan bahwa persistensi pengangguran di Indonesia tidak bisa dikategorikan ke dalam histerisis atau slow adjustment karena koefisien e pada persamaan III.3 dan III.4 seharusnya negatif dan signifikan. Hal ini juga berarti persistensi pengangguran tidak disertai dengan self correcting mechanism dalam fundamental ekonomi.

Ada beberapa implikasi penting dari temuan di atas. Pertama, pemerintah tampaknya tidak bisa mengandalkan mekanisme pasar secara murni untuk mengatasi pengangguran. Harus ada hands on strategy yang didesain secara khusus untuk mengembalikan tingkat pengangguran ke arah kesetimbangan jangka panjang. Pengalaman di Eropa menunjukan bahwa apabila 
tanpa disadari sebuah pemerintahan tidak menyiapkan strategi yang tepat maka tingkat pengangguran akan cenderung memburuk dan berlangsung dalam jangka waktu sampai puluhan tahun. Merupakan kepentingan rakyat Indonesia untuk tidak terjebak pada situasi yang mirip dengan pola pengangguran Eropa Barat.

Kedua, untuk merumuskan strategi kebijakan anti pengangguran, harus terlebih dahulu diidentifiksi faktor-faktor yang menjadi akar penyebab terjadinya persistensi. Tanpa itu maka biasanya kebijakan menjadi tidak efektif dalam mengatasi underlying problem. Bagian selanjutnya mengulas aspek ini.

\section{IV.2.3. Sumber Persistensi Pengangguran}

Selanjutnya untuk menganalisa faktor apa saja yang menjadi sumber persistensi pengangguran regional akan digunakan model yang dikembangkan oleh Wu (2003) ${ }^{10}$.

$U_{t}-U_{t-1}=a+\beta_{1} U_{t-1}+\beta_{2} U_{t-1} *$ sharemanufacture $+\beta_{3} U_{t-1} *$ shareservices $+\beta_{4}$ PDRBgrowth $+\varepsilon_{t}$

Hasil analisis dengan ketiga metode panel, Ordinary Least Square (OLS), Fixed Effect (FE) dan Random Effect(RE), dengan atau tanpa dummy tahun disajikan pada Tabel III.8. Berdasarkan nilai LM test, Hausman test, R-square, dan t-statistik, model yang paling baik adalah model Random Effect dengan dummy tahun (Model 3B).

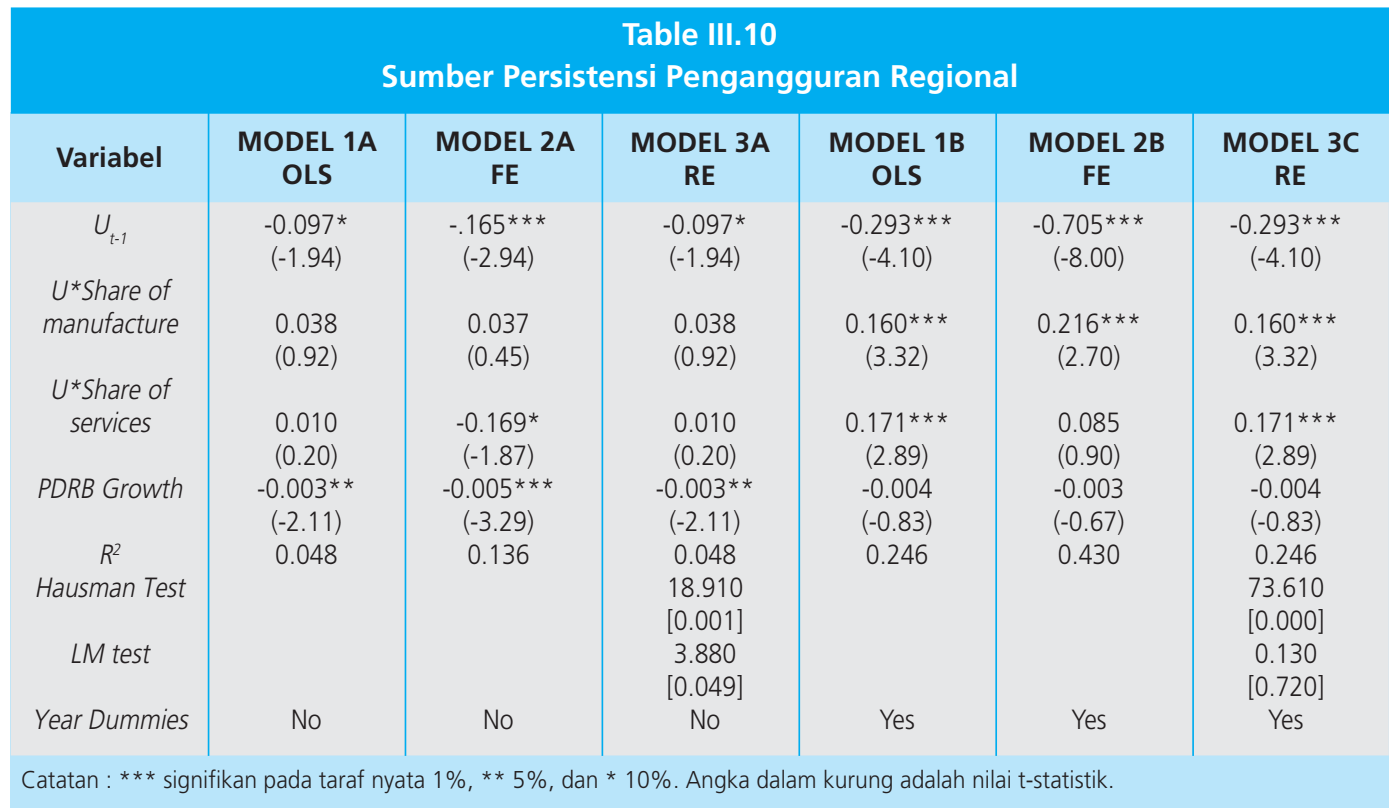

10Dalam model Wu, variabel yang digunakan antara lain adalah share output dari sektor State dan Collective. Untuk kasus Indonesia, kedua sektor ini diganti oleh sektor industri manufaktur dan jasa. 
Model 3B menunjukkan semua variabel kecuali PDRB growth, signifikan mempengaruhi variabel dependent $\left(U_{t}-U_{t-1}\right)$ pada taraf 1 persen. Artinya, bahwa dalam jangka pendek pertumbuhan ekonomi daerah tidak mampu mengurangi masalah persistensi pengangguran regional.

Selain itu, share output sektor manufaktur dan jasa memiliki efek yang positif dan signifikan terhadap persistensi pengangguran. Tingginya persistensi pengangguran regional terjadi karena tingginya share output sektor manufaktur dan jasa. Semakin tinggi share output kedua sektor tersebut, pengangguran regional akan semakin persisten. Rasionalisasi atas fakta ini cukup jelas mengingat kedua sektor teresebut merupakan sektor yang padat modal dengan rasio serapan tenaga kerja yang relatif kecil dibandingkan sektor lainnya. Sektor yang selama ini mampu menyerap mayoritas tenaga kerja adalah sektor pertanian dan pertumbuhan sektor ini diharapkan mampu mengurangi persistensi pengangguran di Indonesia.

Data menunjukkan bahwa elastisitas sektoral penyerapan tenaga kerja dan angkatan kerja yang bekerja pada sektor pertanian lebih tinggi dibandingkan dengan sektor-sektor lainnya (Grafik III.18). Pada tahun 2000, 42.53 persen angkatan kerja berada di sektor ini namun terus menurun hingga menjadi 39.40 persen pada tahun 2006. Berdasarkan elastisitas, sektor pertanian memiliki kemampuan untuk menyerap tenaga kerja sebanyak 0.61 persen untuk setiap 1 persen pertumbuhan PDB sektor tersebut (Tabel III.11). Namun demikian, kemampuan sektor pertanian dalam menyerap tenaga kerja juga sangat dipengaruhi oleh pertumbuhan ekonomi di sektor tersebut yang cenderung menurun serta lebih kecil dibanding sektor manufaktur dan jasa.

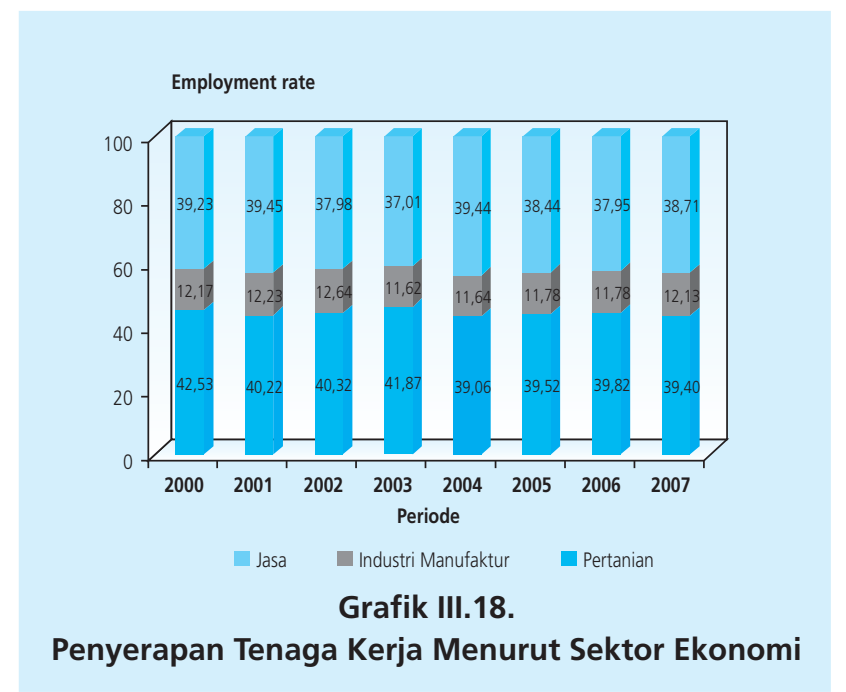




\begin{tabular}{|c|c|c|c|c|}
\hline \multirow[b]{3}{*}{ Periode } & umbu & $\begin{array}{l}\text { le III.11 } \\
\text { B dan PDB Se }\end{array}$ & & \\
\hline & \multicolumn{4}{|c|}{ Pertumbuhan } \\
\hline & PDB & PDB Pertanian & $\begin{array}{l}\text { PDB Industri } \\
\text { Manufaktur }\end{array}$ & PDB Jasa \\
\hline $\begin{array}{l}2001 \\
2002 \\
2003 \\
2004 \\
2005 \\
2006\end{array}$ & $\begin{array}{l}3,64 \\
4,50 \\
4,78 \\
5,03 \\
5,68 \\
5,48\end{array}$ & $\begin{array}{l}3,26 \\
3,45 \\
3,79 \\
2,82 \\
2,66 \\
2,98\end{array}$ & $\begin{array}{l}2,40 \\
4,02 \\
3,40 \\
3,40 \\
4,20 \\
4,02\end{array}$ & $\begin{array}{l}4,89 \\
5,28 \\
6,30 \\
7,13 \\
7,84 \\
7,38\end{array}$ \\
\hline
\end{tabular}

Permasalahan ketenagakerjaan pada dasarnya juga terkait dengan kondisi perekonomian di Indonesia. Terdapat empat hal yang perlu mendapatkan perhatian khusus. Pertama, ketimpangan sektoral dalam penyerapan tenaga kerja. Kedua, perlu reorientasi kebijakan bahwa sektor yang tumbuh relatif tinggi seyogyanya mampu menyerap tenaga kerja lebih tinggi. Ketiga, kebijakan industrialisasi yang pro penciptaan lapangan kerja. Keempat, adanya ketimpangan produktivitas antar sektor.

Untuk melengkapi model ekonometrik ini, bagian berikut ini akan menelusuri dan menganalisis data primer yang telah dikumpulkan dengan focus bagaimana akumulasi modal, kekakuan upah, pencarian kerja dan factor-faktor lainnya dapat berpengaruh terhadap persistensi pengangguran di Indonesia.

\section{Akumulasi Modal}

Dalam era pascakrisis, akumulasi kapital (capital accumulation) menjadi bertambah lamban yang ditunjukkan dengan rasio investasi dan kredit investasi-modal kerja yang lebih rendah dibanding era sebelum krisis (Grafik III.14). Diperkirakan rendahnya rasio investasi tersebut berasosiasi dengan beberapa hal berikut ini. Pertama, terlalu lambatnya proses restrukturisasi perusahaan yang dilakukan oleh BPPN. Akibatnya berbagai barang modal yang dimiliki oleh perusahaan besar seperti Texmaco kemudian terbuang percuma menjadi barang rongsokan. Banyak kasus di mana lambatnya proses restrukturisasi juga mengakibatkan tertutupnya akses fianansial bagi perusahaan tersebut. Perbankan maupun kreditur lainnya tidak bisa menambah pagu kredit sebelum penyehatan perusahaan dirampungkan.

Kedua, bersamaan dengan terjadinya krisis terjadi juga pelarian modal dan pelarian pemilik modal. Kalau hanya modalnya yang lari maka dampaknya hanya terbatas pada jangka menengah saja. Tetapi kalau modal dan pemilik modalnya lari maka dampaknya akan sangat permanen. 
Ketiga, pada saat krisis banyak perusahaan dan wirausaha yang mengalami kebangkrutan. Mereka harus membangun kembali usaha dari awal sehingga tidak bisa melakukan progres investasi secepat sebelumnya. Selain itu, populasi wirausahawan baru relatif masih sangat terbatas sehingga secara totalitas pertumbuhan investasi nasional belum mencapai tingkatan seperti sebelum krisis.

Keempat, sektor perbankan juga bertanggung jawab dalam melambatnya akumulasi modal. Rasio kredit terhadap PDB masih kira-kira setengah dari tingkatan sebelum krisis (Grafik III.19). Dan karena itu, perbankan secara intensif lebih mengembangkan portofolio kredit konsumsi dan sedikit melupakan kredit investasi. Kelima, sektor finansial terutama pasar modal telah menjadi kontraproduktif terhadap sektor riil. Return atas aset-aset finansial jauh lebih tinggi dibanding normal profit yang tercipta oleh sektor riil. Karena itu, pemilik modal menjadi lebih tertarik terhadap instrumen finansial sehingga ketersediaan dana untuk investasi di sektor riil menjadi terbatas.
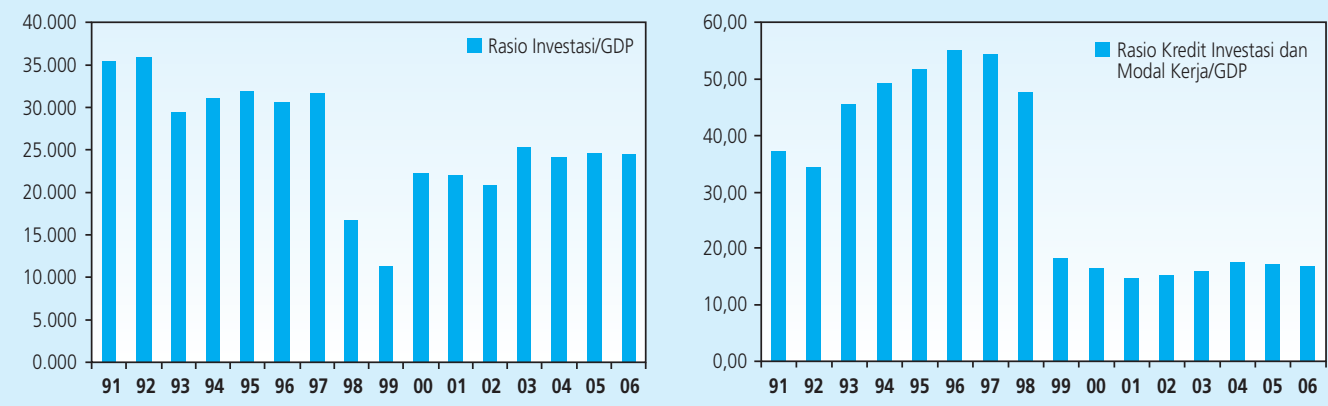

Grafik III.19

Rasio Kredit Investasi dan Modal Kerja Terhadap GDP

Kelima hal tersebut di atas diperkirakan telah menyebabkan laju akumulasi modal menjadi lebih lamban dibandingkan sebelum krisis yang pada gilirannya menyebabkan laju permintaan tenaga kerja juga mengalami masalah. Dalam dinamika selanjutnya, kelima hal tersebut dipadukan dengan kekakuan upah yang akan dibahas dalam bagian di bawah ini secara simultan menyebabkan tingkat pengangguran yang persisten. Karena upah aktual berada di atas equiliubrium maka tingkat profitabilitas perusahaan menjadi tertekan dan sebagai akibat selanjutnya akumulasi modal menjadi bertambah lamban. Lambannya akumulasi modal pada gilirannya dapat mengakibatkan pertumbuhan produktivitas modal menjadi terhambat sehingga tidak mampu mengompensasi beban yang timbul akibat terlalu tingginya upah. 
Dari uraian tersebut di atas, sektor riil tampaknya berada dalam lingkaran setan yang tidak ada satu pelaku pun yang bisa memutusnya. Hal tersebut mensyaratkan adanya langkahlangkah terobosan yang terpadu untuk mengatasi masalah akumulasi modal dan kekakuan upah secara simultan. Jika hanya salah satu saja yang diatasi maka sektor riil masih akan terbelit oleh masalah-masalah tersebut.

\section{Kekakuan Upah}

Kekakuan upah (wage rigidity) sering dipandang sebagai salah satu penyebab utama kenaikan tingkat pengangguran secara berkepanjangan. Pada dasarnya kekakuan upah dikelompokan menjadi dua, yaitu kekakuan upah nominal dan kekakuan upah riil. Kekakuan upah nominal terjadi manakala tingkat upah berada di atas kesetimbangan sehingga terjadi peningkatan pengangguran di atas tingkat pengangguran alamiah. Selisih antara tingkat pengangguran aktual yang diakibatkan oleh kekakuan upah nominal dengan tingkat pengangguran alamiah disebut wait unemployment. Disebut demikian karena para penganggur hanya bisa menunggu kesempatan kerja yang tidak pernah bisa datang. Kekakuan upah nominal bisa diakibatkan oleh downward rigidity, pemberlakuan upah minimum, indeksasi, upah relatif, dan upah efisiensi. Kesemuanya itu berpotensi untuk mengakibatkan upah nominal di atas upah kesetimbangan.

Dari hasil-hasil temuan dalam penelitian ini, dapat disimpulkan bahwa upah nominal bersifat kaku ke bawah (downward rigidity) dan kekakuan itu bersifat tidak simetris dalam arti upah nominal mudah mengalami kenaikan tetapi sulit untuk turun. Berdasarkan data timeseries upah rata-rata, upah nominal hanya pernah sekali mengalami penurunan yaitu di tahun 1998 (Grafik III.20). Berdasarkan hasi survei terhadap perusahaan dan pekerja, kemungkinan besar

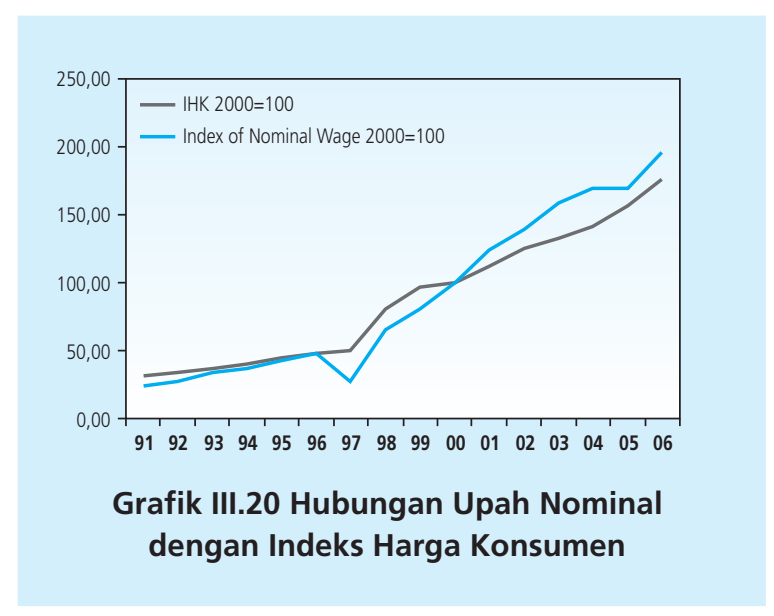


penyebab utama dari kekakuan upah ini adalah besarnya perceived cost yang berasosiasi dengan penurunan upah sehingga perusahaan cenderung sulit mengalami penurunan upah. Hasil survei mengindikasikan bahwa ongkos penurunan upah dimanifestasikan dalam bentuk demo buruh, kehilangan pekerja yang produktif, dan turunnya produktivitas rata-rata pekerja. Ongkos ini mungkin tidak sebanding dengan manfaat penghematan yang tercipta akibat penurunan upah.

Selain hal di atas, kekakuan upah bisa juga merupakan akibat dari pemberlakuan kebijakan upah minimum (Grafik III.21). Dalam kebijakan ini, perusahaan secara legal tidak boleh melakukan kebijakan pengupahan di bawah floor wage. Berdasarkan hasil survei terhadap perusahaan dan pekerja ditemukan bukti kuat bahwa kebijakan upah minimum telah mampu melindungi sebagian besar pekerja. Tetapi kenyataan bahwa sebagian kecil pekerja dibayar di bawah upah minimum menunjukkan kebijakan tersebut belum sepenuhnya efektif. Ditemukan juga bahwa upah minimum merupakan upah referensi bagi perusahaan dalam menetapkan kebijakan tingkat upah.

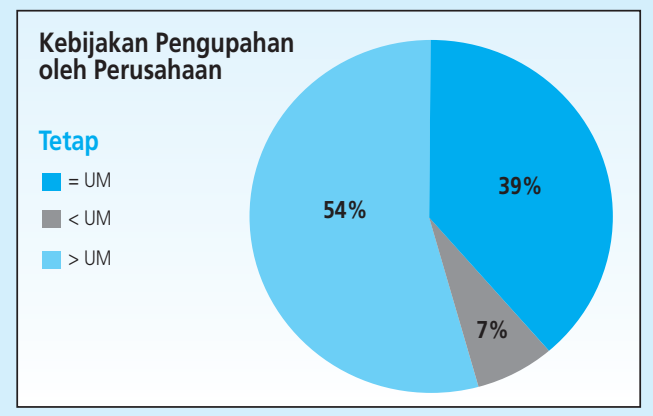

Catatan : UM adalah Upah Minimum

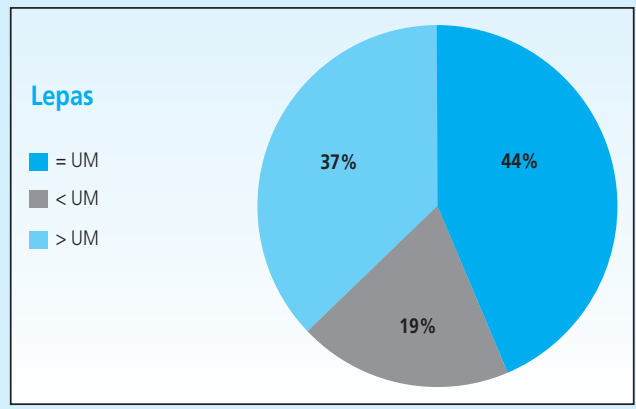

Catatan : UM adalah Upah Minimum

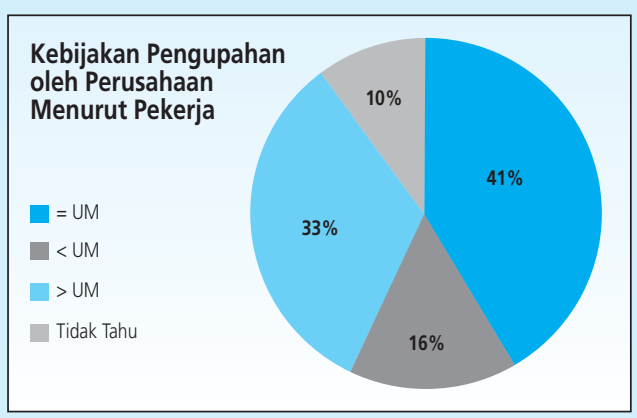

Catatan : UM adalah Upah Minimum.

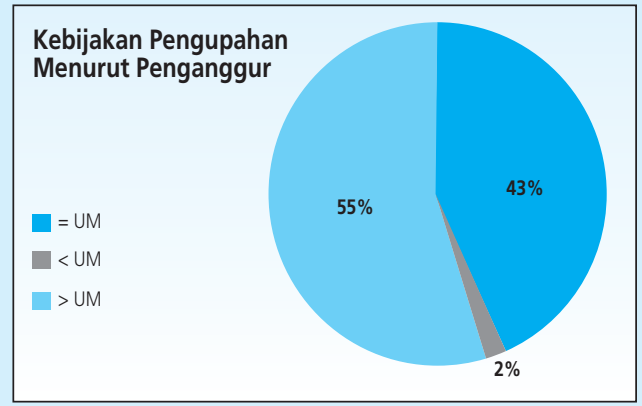

Catatan : UM adalah Upah Minimum.

Grafik III.21

Respon Perusahaan, Pekerja, dan Penganggur Terhadap Kebijakan Pengupahan 
Temuan survei mengenai kekakuan upah ke bawah dan upah minimum menimbulkan pertanyaan yang sangat mendasar yaitu manakah di antara keduanya yang lebih dominan atau menjadi alasan utama kekakuan upah nominal. Menilik besarnya respon responden perusahaan dan pekerja, secara implisit mengindikasikan bahwa mahalnya perceived cost kemungkinan lebih penting dibandingkan dengan upah minimum. Atau dengan kata lain, seperti yang dikatakan oleh John Maynard Keynes, kekakuan upah ke bawah merupakan social fact of life yang memiliki dimensi keadilan sosial dan upah relatif. Implikasinya adalah kalau pun upah minimum tidak diberlakukan maka itu tidak menjadikan hilangnya kekakuan upah.

Kekakuan upah menjadi lebih kompleks ketika upah minimum diindeksasi terhadap inflasi. Dari hasil survei ditemukan bahwa upah minimum disesuaikan dengan inflasi secara backward dan forward (Grafik III.22). Dari hasil estimasi ekonometrika juga ditemukan bukti kuat mengenai indeksasi, terutama dalam periode setelah krisis. Dalam periode ini bahkan ditemukan koefisien indeksasi yang lebih besar dari satu baik untuk backward maupun forward. Artinya, upah minimum mengalami penyesuaian yang lebih tinggi dibanding tingkat inflasi.

Implikasi terpenting dari temuan ini adalah kemungkinan tidak efektifnya kebijakan moneter yang bersifat ekspansif dalam mengatasi pengangguran. Kebijakan moneter yang berusaha mendorong anticipated inflation maupun unanticipated inflation sama sekali tidak efektif karena akan dikompensasi oleh mekanisme indeksasi secara backward maupun forward yang terlalu berlebihan. Yang tercipta malahan adalah inflasi yang persisten tanpa memiliki pengaruh terhadap tingkat pengangguran. Dalam situasi seperti ini, kebijakan inflation targeting dengan sasaran inflasi jangka panjang yang lebih rendah menjadi lebih relevan.

Faktor indeksasi UM menurut perusahaan:

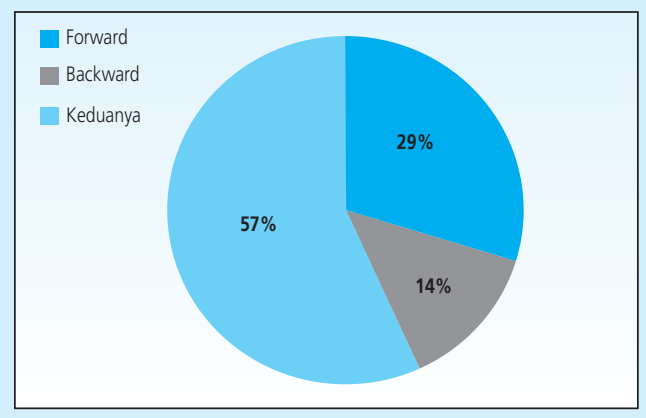

Faktor indeksasi UM menurut pekerja:

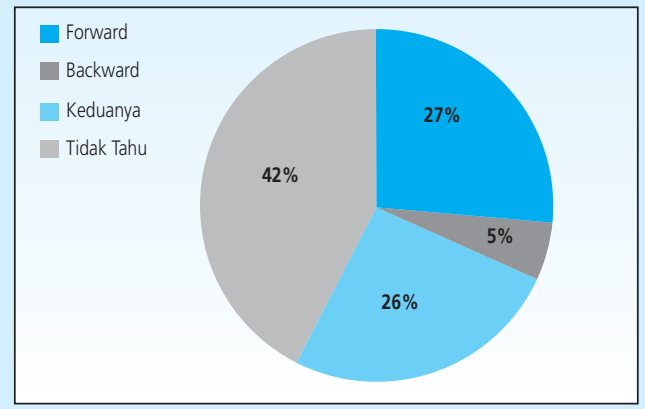

Grafik III.22

Indeksasi Upah Menurut Perusahaan dan Pekerja 

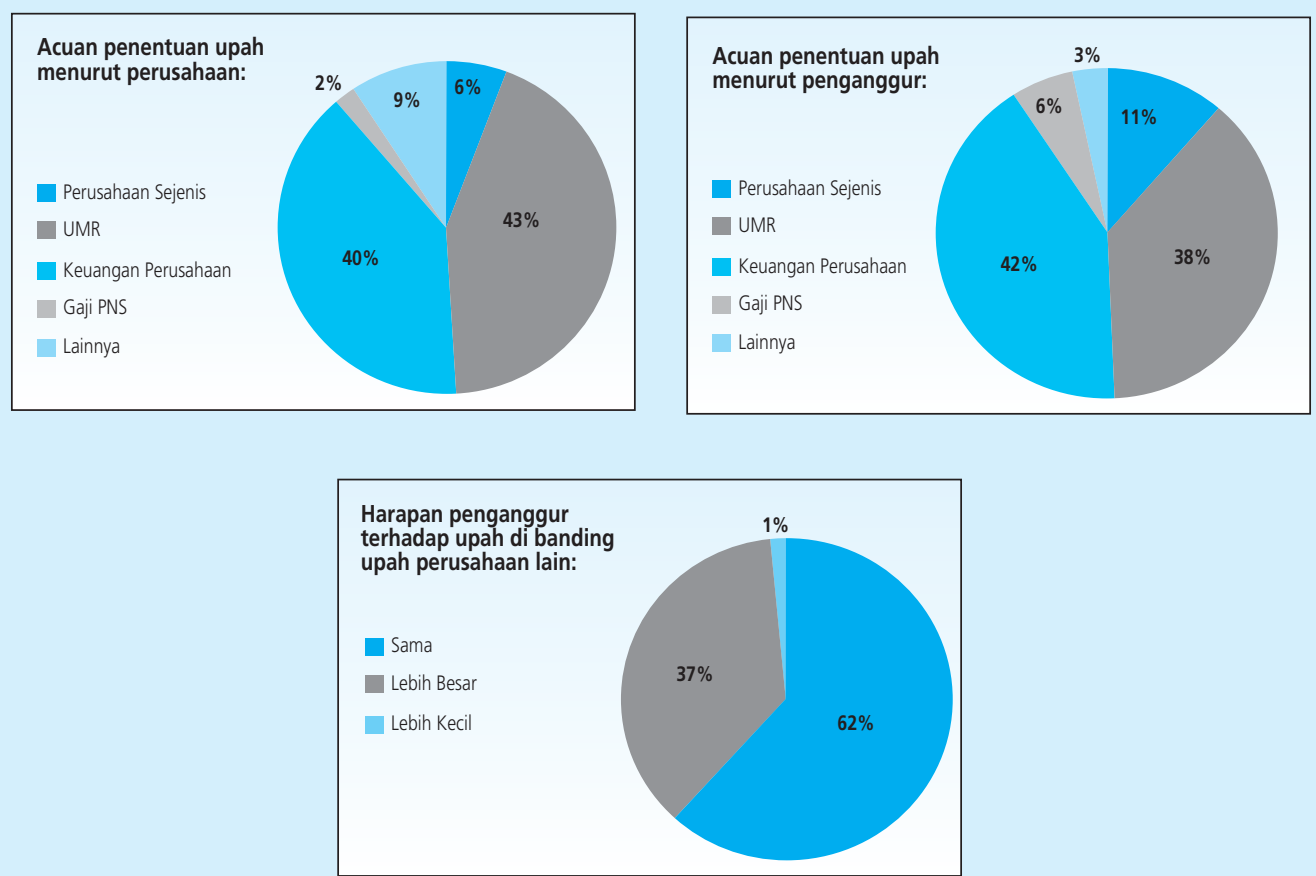

Grafik III.23

Indikasi Upah Relatif Menurut Perusahaan dan Pekerja

Dalam penelitian yang ada, tidak ditemukan bukti yang kuat bahwa upah relatif dan upah efisiensi menjadi penyebab kekakuan upah nominal (Grafik III.23 dan Grafik III.24). Alasannya sederhana; dalam situasi di mana pengangguran sedang tinggi dan meningkat, perusahaan memiliki ruang untuk tidak saling bersaing memberikan upah yang lebih kompetitif dalam mencari tenaga kerja. Hal ini juga didukung oleh temuan bahwa mayoritas perusahaan dapat memperoleh pekerja untuk mengisi lowongan dalam tempo yang singkat, yaitu kurang dari satu bulan. Fakta berikutnya yang jauh lebih penting adalah fenomena kekakuan upah riil. Fenomena ini terjadi manakala upah riil yang dibayarkan kepada pekerja melebihi marginal productivity of labor (MPL). Keseimbangan pasar seharusnya terjadi ketika MPL sama dengan upah riil.

Hasil survei terhadap perusahaan dan pekerja menunjukan bahwa perusahaan mengalami kesulitan untuk melakukan penyesuaian upah riil ketika perusahaan mengalami guncangan produktivitas. Hal ini juga didukung oleh hasil estimasi ekonometrika di mana pertumbuhan upah riil kurang lebih sama dengan warranted real wage dalam periode setelah 


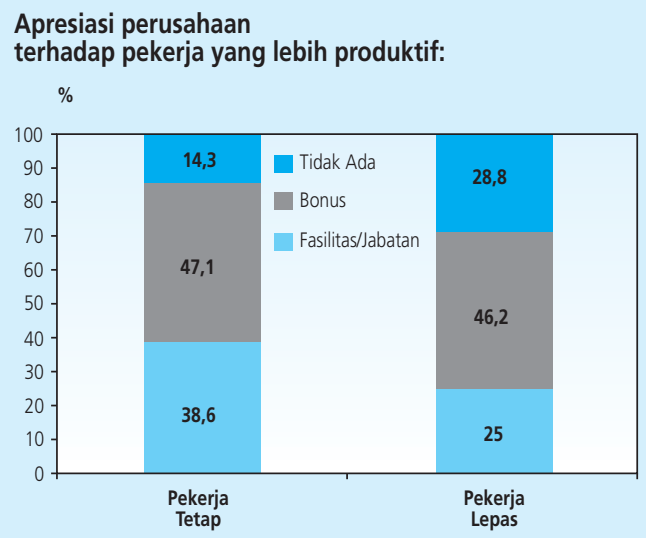

\section{Yang diterima pekerja} jika lebih produktif:

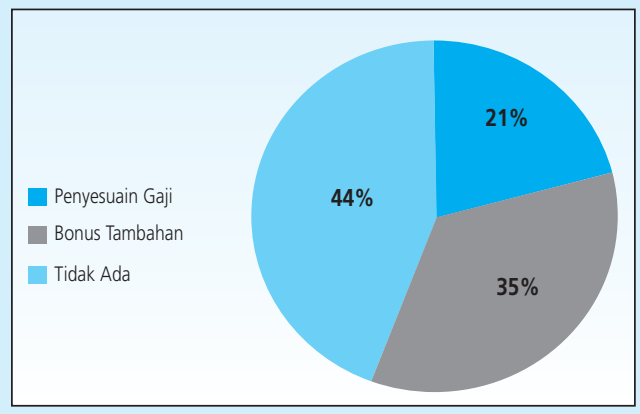

\section{Grafik III.24}

Indikasi Upah Efisiensi Menurut Perusahaan dan Pekerja

krisis (Tabel III.12). Seharusnya ketika pengangguran mengalami peningkatan, pertumbuhan upah riil lebih rendah dibanding warranted real wage supaya kesempatan kerja menjadi terbuka lebih lebar. Akibat dari fenomena ini, maka wage share cenderung mengalami penurunan dari waktu ke waktu yang mengindikasikan bahwa perusahaan berusaha untuk mengurangi beban upah tenaga kerja.

\begin{tabular}{|c|c|c|c|c|c|c|}
\hline & & resi Upah & $\begin{array}{l}\text { abel III. } 1 \\
\text { dan War }\end{array}$ & d Real W & & \\
\hline Dependen & Warrant & $\begin{array}{l}\text { enden Va } \\
\text { al Wages }\end{array}$ & on TFP1 & Warrante & $\begin{array}{l}\text { yenden Va } \\
\text { al Wages }\end{array}$ & d on TFP2 \\
\hline & '91 - '96 & '99 - '06 & '91 - '06 & '91 - '96 & '99 - 06 & '91 - 06 \\
\hline Upah Riil & $0.98 * * *$ & $1.03 * * *$ & $0.97 * * *$ & $0.89 * * *$ & $1.01 * * *$ & $0.92 * * *$ \\
\hline $\begin{array}{l}\text { Catatan: } \\
\text { Warranted Real } \\
\text { Sebagai variabel } \\
\text { TFP1 mengguna } \\
\text { TFP2 mengguna } \\
* * * \text { signifikan } p\end{array}$ & $\begin{array}{l}\mathrm{S}=\text { Total Fact } \\
\text { al: } \\
\text { ross Fixed Ca } \\
\text { onsumption } \\
\text { araf nyata } 1 \%\end{array}$ & $\begin{array}{l}\text { uctivity (TFP) } \\
\text { rmation (GF } \\
\text { Capital (CF }\end{array}$ & nare. & & & \\
\hline
\end{tabular}

Ada dua implikasi penting dari kekakuan upah riil. Pertama, untuk mengurangi tingkat pengangguran atau lebih tepatnya lagi membuka kesempatan kerja yang lebih luas, maka pemerintah bisa merekayasa supaya pertumbuhan upah riil selalu berada di bawah pertumbuhan warranted real wage. Hal ini bisa dicapai dengan penetapan upah minimum yang lebih lambat dibandingkan inflasi. Tetapi dalam kenyataannya sebagaimana telah dibahas, strategi ini dianggap sulit untuk diwujudkan dan malahan bisa kontraproduktif. 
Kedua, sebagai alternatifnya pemerintah bisa mendorong warranted real wage untuk tumbuh jauh lebih cepat. Syarat utamanya adalah meningkatkan total factor productivity (TFP). Terdengarnya ini mudah untuk dikatakan, tetapi dalam kenyataannya sulit untuk diwujudkan. Untuk meningkatkan TFP perlu dilakukan langkah-langkah sebagai berikut: (1) melakukan akselerasi akumulasi modal, (2) meningkatkan efisiensi investasi, dan (3) meningkatkan kualitas sumberdaya manusia (SDM). Ketiganya tersebut tidak bisa dilakukan dalam jangka pendek.

Berdasarkan diskusi di atas, persistensi pengangguran yang terjadi selama ini kemungkinan besar merupakan akibat dari kekakuan upah nominal maupun kekakuan upah riil. Tampaknya kedua jenis kekakuan upah tersebut relatif sulit untuk dipecahkan, walaupun bukan sesuatu hal yang tidak mungkin.

\section{Pencarian Kerja}

Trend unemployment bisa mengalami peningkatan jika laju perkembangan kesempatan kerja lebih lambat dibanding laju pertumbuhan pencari kerja. Konsekuensinya, waktu yang dibutuhkan untuk pencarian kerja (job search) menjadi lebih lama. Pencarian kerja sangat dipengaruhi oleh beberapa faktor berikut: sectoral shift, friksi, mismatch, ketidaksempurnaan informasi, geographic barier, dan upah reservasi.

Perubahan komposisi sektoral (sectoral shift) dalam perekonomian nasional sudah lama ditengarai sebagai salah satu sumber semakin tingginya tingkat pengangguran. Tingkat pengangguran alamiah dapat meningkat sebagai akibat dari sulitnya para pencari kerja untuk berpindah dari sektor yang sedang menurun ke sektor yang sedang berkembang pesat. Setiap sektor mensyaratkan kualifikasi dan jenis pengalaman yang berbeda-beda sehingga diperlukan proses re-training dan re-tooling bagi para pekerja yang berpindah sektor. Selain itu sektor yang mengalami perkembangan yang sangat cepat belum tentu dapat menyediakan kesempatan kerja secepat laju pertumbuhan angkatan kerja.

Dari hasil analisis elastisitas sektoral sebagaimana dijelaskan pada Tabel III.13, diperoleh bukti bahwa elastisitas penyerapan tenaga kerja di sektor jasa (0.253) lebih rendah dibanding sektor manufaktur (0.406) dan elastisitas penyerapan tenaga kerja sektor manufaktur lebih rendah daripada pertanian (0.606). Hal ini juga konsisten dengan temuan lainnya yang menunjukan bahwa di provinsi-provinsi yang pangsa sektor manufaktur dan jasanya lebih tinggi ternyata tingkat penganggurannya lebih persisten. Padahal tingkat pertumbuhan ekonomi sektor jasa dan sektor manufaktur cederung selalu lebih tinggi dibanding sektor pertanian. 


\begin{tabular}{|c|c|c|}
\hline & $\begin{array}{c}\text { Tabel III. } 13 \\
\text { s Sektoral Tena }\end{array}$ & \\
\hline Sektor & Nilai Elastisitas & $\mathbf{R}^{2}$ \\
\hline $\begin{array}{c}\text { Pertanian } \\
\text { Industri (Manufaktur) } \\
\text { Jasa }\end{array}$ & $\begin{array}{l}0.606 * * * \\
0.406 * * * \\
0.253 * * *\end{array}$ & $\begin{array}{l}0.4649 \\
0.7772 \\
0.9984\end{array}$ \\
\hline
\end{tabular}

Kemajuan perekonomian biasanya ditandai dengan pergeseran peran sektoral dari dominasi pertanian ke manufaktur dan kemudian ke jasa. Padahal, sebagaimana telah diungkapkan di atas, elastisitas penyerapan tenaga kerjanya semakin rendah. Dengan demikian secara alamiah pergeseran sektor ini akan selalu diikuti dengan meningkatnya pengangguran alamiah. Implikasi penting dari temuan di atas adalah diperlukan sebuah strategi untuk meningkatkan kualitas pertumbuhan dengan cara mendorong sebagian sektor manufaktur dan jasa yang bersifat labor intensive. Akan tetapi kesulitannya adalah pemilihan teknologi produksi sepenuhnya berada di tangan perusahaan yang murni didorong oleh motif mencari keuntungan. Selama teknologi padat tenaga kerja konsisten dengan motif mencari keuntungan maka perusahaan akan lebih memilih teknologi padat tenaga kerja. Dengan demikian yang harus dilakukan oleh pemerintah adalah mengembangkan produk intensif untuk pengembangan teknologi padat tenaga kerja dan disinsentif untuk teknologi padat modal.

Jika masalah sectoral shift tidak ditangani, maka akan timbul masalah yang lebih besar dalam pengangguran friksional. Jenis pengangguran ini timbul manakala seorang tenaga kerja melakukan perpindahan dari satu pekerjaan ke pekerjaan lainnya dan harus menunggu dengan jangka waktu tertentu.

Meningkatnya pengangguran friksional biasanya ditandai oleh semakin sulitnya melakukan perpindahan pekerjaan. Mayoritas responden pekerja menyatakan sulit untuk mendapatkan pekerjaan yang lebih cocok dengan keahlian dan pengalaman (Grafik III.25). Artinya, pekerja mengalami kesulitan untuk melakukan perpindahan pekerjaan.

Kesulitan dalam mencari pekerjaan yang sesuai dengan kualifikasi juga dialami oleh para penganggur (86 persen) sebagaimana dijelaskan pada Grafik III.26. Jadi secara umum para penganggur bisa dikatakan tidak memiliki kualifikasi yang sesui dengan lowongan pekerjaan yang tersedia. Fenomena ini dikenal sebagai mismatch. Kemungkinan besar mismatch merupakan akibat dari ketidaksesuaian sistem pendidikan dengan perubahan struktural dalam perekonomian. Hal ini juga terbukti dengan lebih tingginya tingkat pengangguran yang dialami oleh mereka yang memiliki latar belakang pendidikan umum dibandingkan dengan mereka 


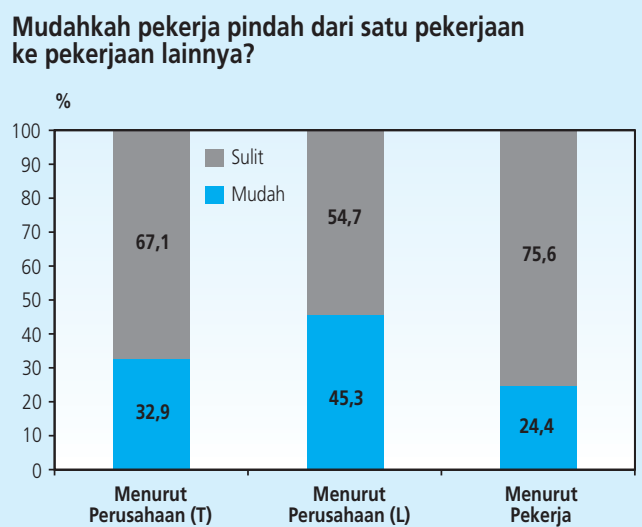

\section{Faktor-faktor yang mempengaruhi} kemudahan pindah pekerjaan:

\begin{tabular}{|c|c|}
\hline Faktor & Persentase \\
\hline Perbedaan keahlian & 36,10 \\
\hline Usia pekerja & 13,28 \\
\hline Lokasi pekerjaan & 11,20 \\
\hline Keinginan pribadi & 11,20 \\
\hline Kualifikasi individu & 20,75 \\
\hline Transfer keahlian & 7,47 \\
\hline
\end{tabular}

\section{Bersediakah penganggur bekerja di sektor yang berbeda?}

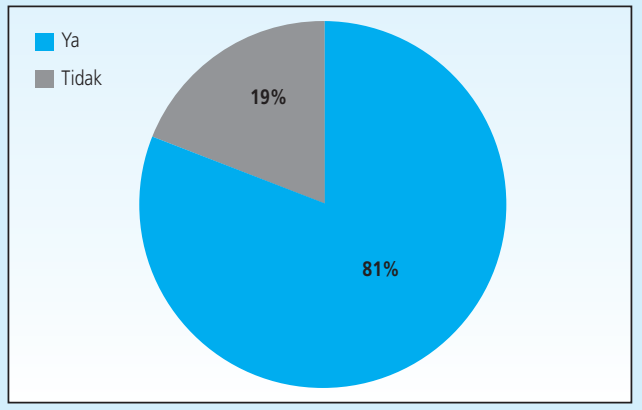

\section{Grafik III.25}

Tingkat Kesulitan dalam Pindah Pekerjaan

yang berlatarbelakang kejuruan. Lulusan pendidikan kejuruan tampaknya lebih siap bekerja dan oleh perusahaan dipandang sebagai sumber tenaga kerja yang siap pakai. Karenanya, biaya rekrutmen dan pelatihan yang dikeluarkan oleh perusahaan lebih rendah dibandingkan dengan pekerja yang berasal dari sekolah umum.

Implikasi dari temuan ini mengisyaratkan bahwa perlu ada perubahan yang mendasar dalam sistem pendidikan nasional menuju sistem yang berbasis kepada keahlian. Akan tetapi masalah ini tidak bisa diselesaikan dalam waktu yang relatif singkat karena membutuhkan penyediaan infrastruktur dan pengajar. Selain itu, stigma yang bekerja di masyarakat bahwa pendidikan kejuruan lebih imperior harus dikikis. Yang terakhir ini tampaknya lebih sulit untuk dilakukan. 


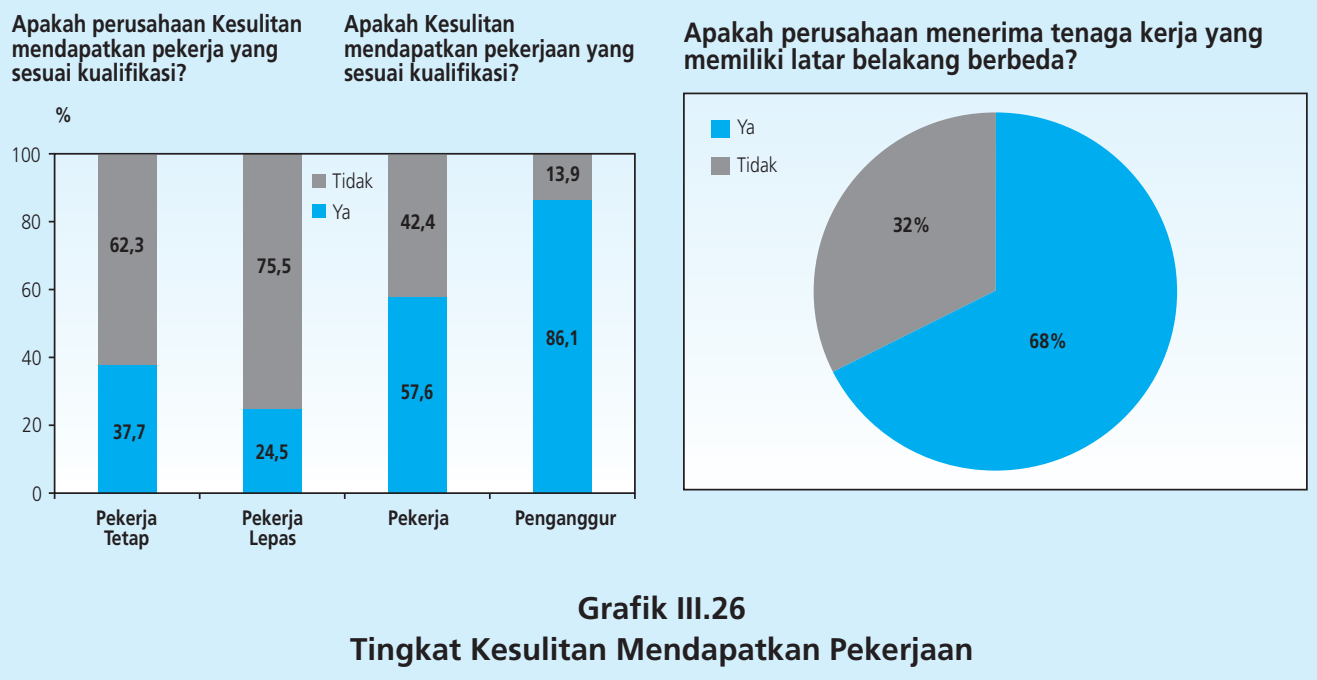

Peningkatan pengangguran terkadang bukan semata-mata diakibatkan oleh ketidaktersediaan lapangan kerja tetapi juga oleh hambatan informasi dan hambatan geografis sebagaimana dijelaskan pada Tabel III.14 dan Grafik III.27. Hambatan informasi terutama diperoleh mereka yang berpendidikan rendah. Mereka pada umumnya mendapatkan informasi lowongan kerja dari mulut ke mulut dan hanya sedikit saja yang melalui media massa. Kemungkinan besar mereka memang tidak terbiasa membaca atau mengakses informasi dari media massa karena masalah daya beli. Selain itu ternyata memang informasi lowongan kerja yang tersedia di surat kabar untuk golongan pendidikan rendah dan tidak berpengalaman hanya sekitar 20 persen dari seluruh informasi lowongan kerja yang diiklankan. Lebih menyedihkan lagi ternyata dinas ketenagakerjaan bukan merupakan sumber utama dalam mencari informasi lowongan kerja bagi calon pekerja (Tabel III. 14). Hal ini menandakan bahwa

\begin{tabular}{l|c|c|}
\multicolumn{2}{c}{ Table III. 14 } \\
Instrumen Informasi Lowongan Pekerjaan
\end{tabular}


kemungkinan besar informasi yang bisa didapatkan dari dinas tenaga kerja memang relatif terbatas jika dibandingkan dengan yang tersedia di media massa ataupun jasa-jasa pengerah tenaga kerja. Karena itu fungsi penyediaan informasi di dinas tenaga kerja wajib diperkuat.
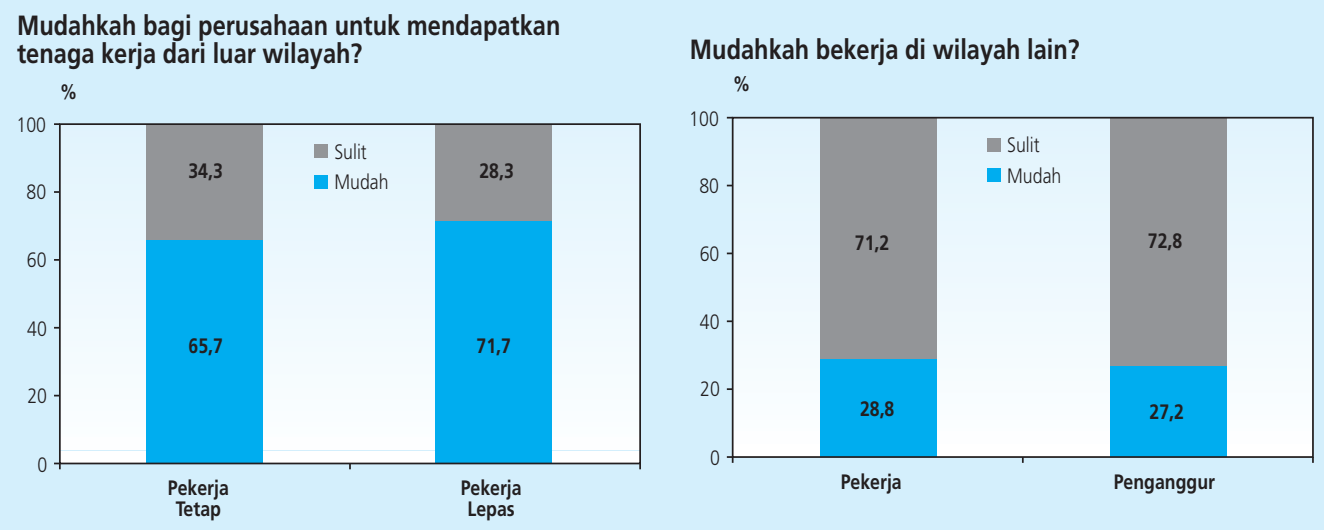

Faktor yang mempengaruhi mobilitas geografis

\begin{tabular}{|l|c|c|}
\hline \multicolumn{1}{|c|}{ Faktor } & Pekerja & Penganggur \\
\hline Hubungan keluarga & 34,4 & 56 \\
\hline Biaya pindah & 20,4 & 10,7 \\
\hline Perbedaan biaya hidup & 22,5 & 17,3 \\
Memang tidak mau pindah & 7,2 & 8 \\
\hline Perbedaan budaya & 4,4 & 1,3 \\
Lainnya & 11,5 & 6,7 \\
\hline
\end{tabular}

Grafik III.27

Tingkat Kesulitan dalam Mobilitas Pekerjaan

Faktor berikutnya yang menjadi penghambat pencarian kerja adalah faktor geografis. Fakta pokok bahasan sebelumnya menunjukkan terdapatnya disparitas yang tajam dalam pengangguran di tingkat provinsi. Provinsi yang berdekatan sekalipun ternyata bisa memiliki perbedaan tingkat pengangguran yang cukup besar. Contohnya adalah provinsi Banten yang memiliki tingkat pengangguran lebih rendah 5 persen dibandingkan DKI Jakarta dan Jawa Barat. Dalam analisis ekonometrika ditunjukkan bahwa disparitas antarprovinsi tersebut lebih disebabkan oleh perbedaan struktur perekonomian. Provinsi yang relatif lebih maju di mana sektor manufaktur dan jasa memiliki pangsa yang lebih besar cenderung memiliki tingkat pengangguran yang lebih tinggi dan lebih persisten. 
Dari hasil survey terhadap pekerja dan penganggur diperoleh gambaran yang relatif berbeda. Alasan utama untuk tidak bekerja di daerah lain ternyata bukan faktor ekonomis melainkan faktor psikologis (keluarga) dan perbedaan budaya (Grafik III.27). Implikasi dari hambatan geografis pencarian kerja adalah bahwa tidak cukup bila pemerintah berupaya menjalankan program penciptaan lapangan kerja yang sangat generik tanpa membedakan karakteristik pengangguran di setiap daerah. Dengan kata lain setiap daerah harus memiliki program antipengangguran sendiri. Secara implisit, hal ini menuntut kreativitas dari pemerintah daerah.

Faktor terakhir yang mungkin paling penting dalam mempengaruhi lamanya pencarian kerja adalah upah reservasi (reservation wage). Semakin tinggi upah yang diinginkan oleh penganggur, semakin sulit untuk mendapatkan pekerjaan dan semakin lama waktu yang dikorbankan untuk menunggu pekerjaan. Yang paling mengejutkan adalah kenyataan bahwa upah reservasi yang diajukan para penganggur tidak terdidik cenderung lebih tinggi dibanding upah minimum (Tabel III.15). Walaupun ini lebih mencerminkan ekspektasi mengenai tingkat upah, tetapi hal tersebut sangat tidak lazim dalam situasi pengangguran yang tinggi. Perilaku semacam ini cenderung mempersulit posisi para penganggur sendiri sebab upah yang mereka harapkan lebih tinggi dibanding upah yang sebagian besar diterima pekerja. Konsisten dengan teori, ternyata temuan dalam penelitian ini menunjukan penurunan dalam upah reservasi berkorelasi dengan lamanya waktu menganggur. Semakin lama menganggur semakin rendah upah reservasi.

\begin{tabular}{|c|c|c|}
\hline \multicolumn{3}{|c|}{$\begin{array}{c}\text { Tabel III.15 } \\
\text { Penurunan Upah Reservasi Terhadap Upah Minimum }\end{array}$} \\
\hline \multirow{2}{*}{ Lama Menganggur } & \multicolumn{2}{|c|}{ Persentase penurunan upah } \\
\hline & Pekerja & Penganggur \\
\hline $\begin{array}{l}1 \text { bulan } \\
3 \text { bulan } \\
6 \text { bulan } \\
12 \text { bulan }\end{array}$ & $\begin{array}{l}25,07 \\
26,02 \\
28,29 \\
31,96\end{array}$ & $\begin{array}{l}24,8 \\
27,6 \\
31,4 \\
35,3\end{array}$ \\
\hline Lama Menganggur & Jumlah Penganggur (\%) & Penurunan upah (\%) \\
\hline $\begin{array}{l}1 \text { bulan } \\
3 \text { bulan } \\
6 \text { bulan } \\
12 \text { bulan } \\
>12 \text { bulan }\end{array}$ & $\begin{array}{c}62,5 \\
13,82 \\
6,58 \\
1,97 \\
15,13\end{array}$ & $\begin{array}{c}24,84 \\
22,50 \\
21,53 \\
47 \\
0\end{array}$ \\
\hline
\end{tabular}


Di negara seperti Indonesia dimana sistem jaminan sosial belum dikembangkan secara baik dan meluas, hampir bisa dipastikan bahwa upah reservasi melulu dipengaruhi oleh preferensi dan ekspektasi para penganggur. Biasanya penganggur yang memiliki upah reservasi tinggi adalah mereka yang bisa membiaya masa menganggurnya.

\section{Faktor Lainnya}

Selain faktor-faktor di atas, terdapat hal-hal lainnya yang secara bersamaan dapat mempengaruhi kekakuan upah dan pencarian kerja. Faktor-faktor tersebut dapat dikelompokan menjadi tiga, yakni regulasi, peran serikat pekerja, dan mekanisme penyesuaian. Di antara aspek regulasi yang paling kelihatan pengaruhnya terhadap kekakuan upah dan pencarian kerja adalah aturan mengenai pesangon dan asuransi sosial. Peratuan mengenai pesangon secara potensial akan meningkatkan upah reservasi yang pada gilirannya memperburuk

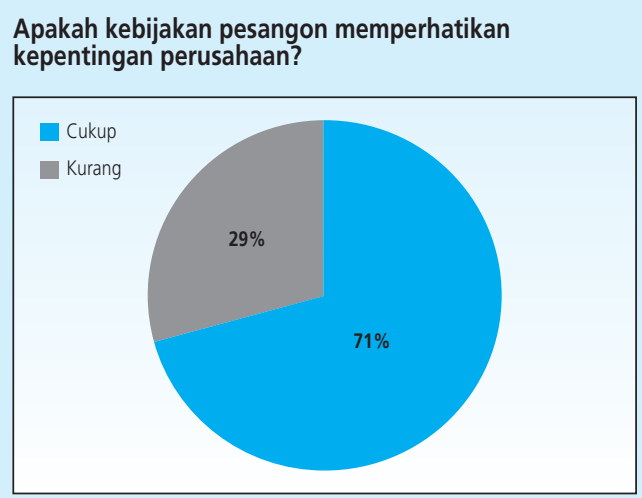

Apakah perusahaan memberikan fasilitas Jamsostek atau asuransi lain?

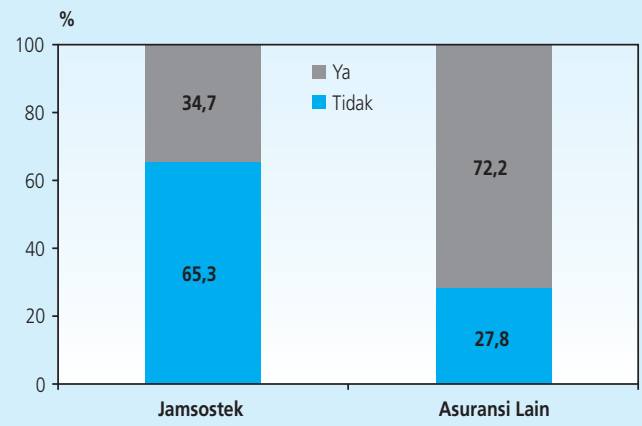

Pesangon itu...

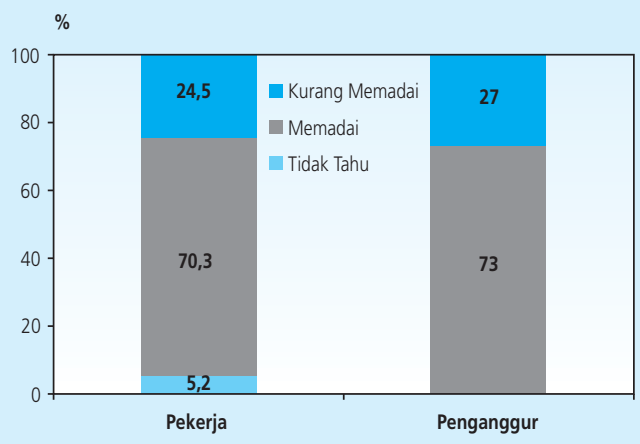

Apakah pekerja mendapatkan fasilitas Jamsostek atau asuransi lain?

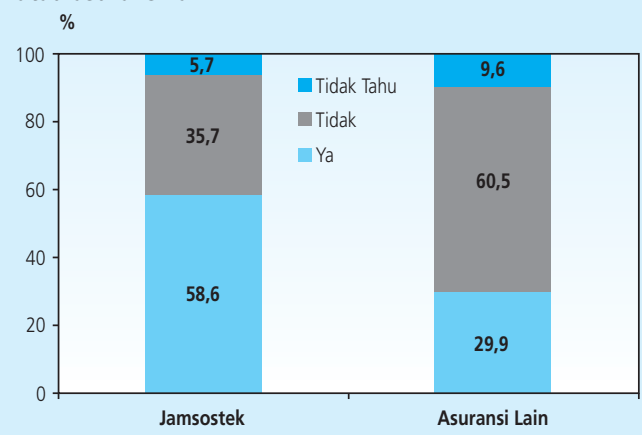

Grafik III.28 Tanggapan Pengusaha, Pekerja, Penganggur Terhadap Pesangon, Jamsostek, dan Asuransi Lainnya 
persistensi pengangguran. Di dalam survei juga ditemukan bukti bahwa peraturan mengenai pesangon dipandang oleh pekerja dan perusahaan sebagai kebijakan yang telah mengakomodasi kepentingan kedua belah pihak (Grafik III.28). Karena itu, kebijakan pesangon secara realistis sulit untuk dicabut atau dikurangi selama tidak mendapatkan dukungan politis baik dari pekerja maupun perusahaan.

Kebijakan mengenai jaminan sosial tenaga kerja walaupun sudah menjadi kewajiban bagi setiap perusahaan untuk menyediakannya, tetapi ada sekitar sepertiga dari perusahaan yang tidak mematuhi. Hal ini konsisten dengan hasil survei terhadap pekerja yang menunjukan lebih dari sepertiga pekerja tidak terlindungi oleh jaminan sosial. Kemungkinan besar perusahaan merasa bahwa beban premi yang harus ditanggung terlalu tinggi. Yang selalu menjadi bahan perdebatan di kalangan akademisi dan politisi adalah peranan serikat pekerja yang fungsinya adalah menyatukan kekuatan kerja individual untuk menghadapi perusahaan yang memiliki
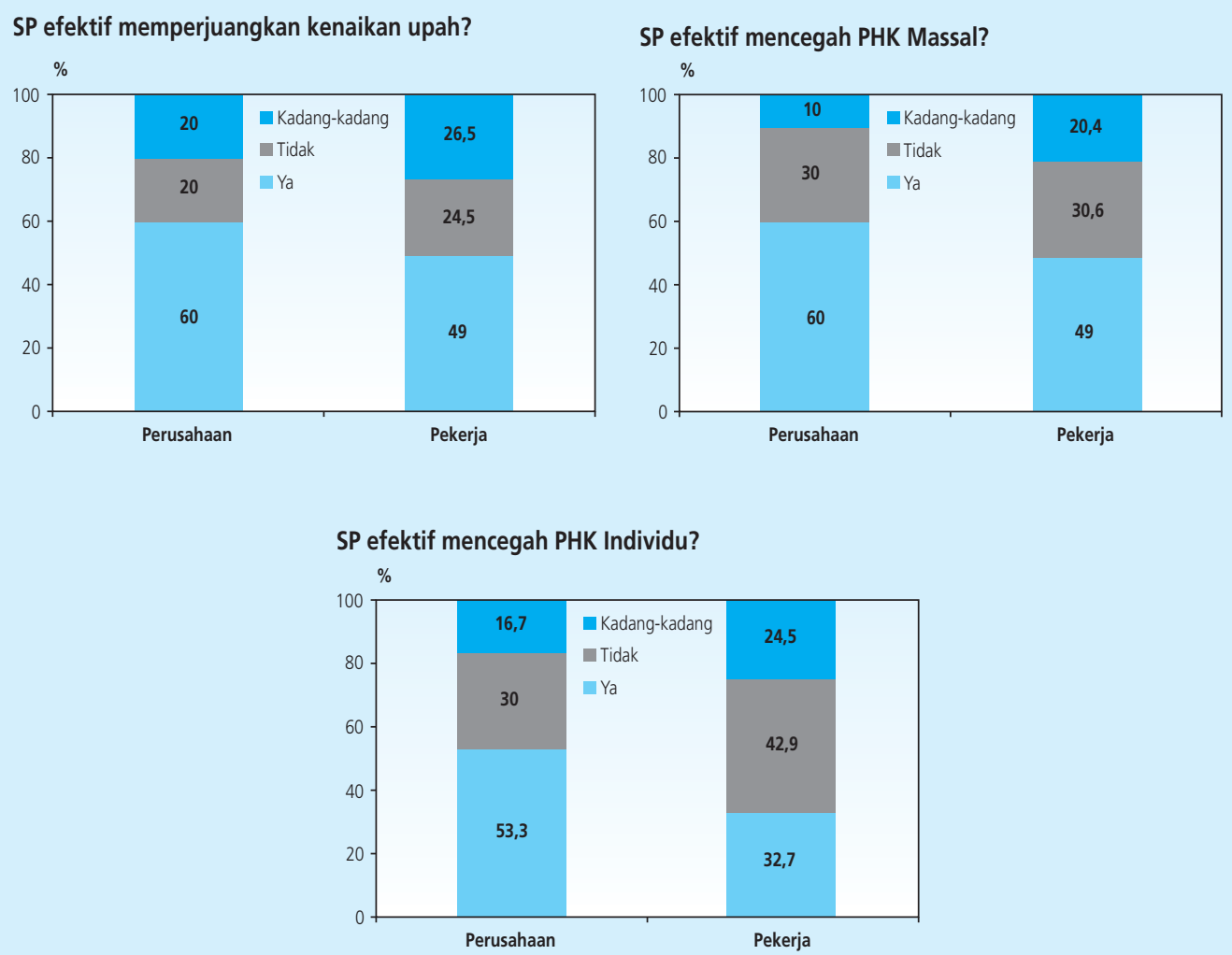

Grafik III.29 Tanggapan Pengusaha, Pekerja, Penganggur Terhadap Serikat Pekerja 
kekuatan monopsoni. Serikat pekerja biasanya dipandang sebagai kekuatan monopoli yang dapat mempengaruhi secara kolektif keputusan pengupahan yang dilakukan oleh perusahaan. Hal ini disebut sebagai collective bergaining.

Dari temuan survei didapatkan gambaran bahwa perusahaan memandang serikat pekerja dapat secara efektif memperjuangkan kenaikan upah. Walaupun demikian, ternyata pekerja tidak memiliki pandangan yang terlalu optimistis dibanding perusahaan (Grafik III.29). Kemungkinan besar pihak manajemen perusahaan sudah memiliki asumsi bahwa perjuangan serikat pekerja dalam menentukan kenaikan upah cenderung memiliki tingkat kesuksesan yang lumayan. Serikat pekerja juga berfungsi untuk mewakili kepentingan para pekerja dalam mempertahankan pekerjaan mereka. Perusahaan dan pekerja ternyata memiliki persepsi bahwa serikat pekerja pada umumnya dapat mencegah terjadinya PHK massal. Namun demikian pencegahaan PHK individual yang dilakukan serikat pekerja tidak dianggap cukup efektif. Artinya, peran serikat pekerja lebih memiliki dimensi kolektif: kenaikan upah seluruh karyawan dan bernegosiasi dengan perusahaan untuk mencegah terjadinya PHK massal.

Yang paling mengherankan adalah persepsi dari para penganggur mengenai peran serikat pekerja. Seharusnya, mereka memiliki sifat yang antipati. Tetapi dari survei menunjukan bahwa penganggur memiliki rasa simpati terhadap serikat pekerja dan memandang eksistensinya sebagai sesuatu hal yang bermanfaat (Grafik III.29). Padahal, serikat pekerja memiliki kontribusi dalam mempersulit posisi para pencari kerja.

Menyikapi semakin sulitnya memperoleh pekerjaan, para penganggur pada umumnya memiliki kemampuan untuk melakukan penyesuaian terutama melalui downskilling. Penganggur

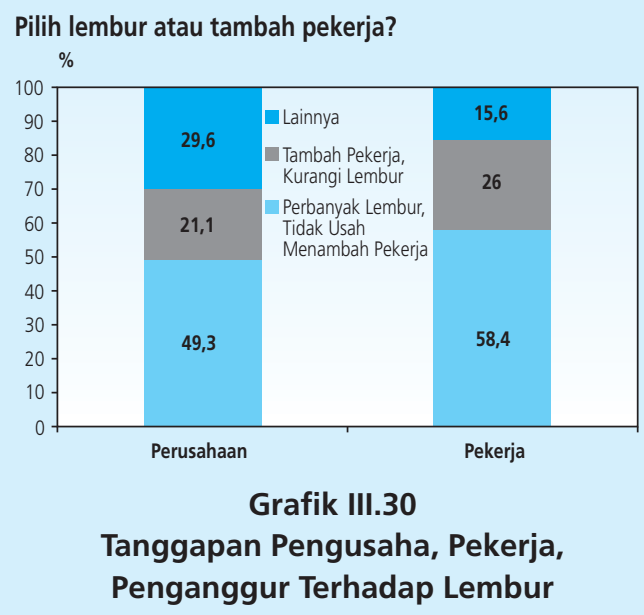


bersedia untuk dipekerjakan di posisi yang memiliki persyaratan pendidikan dan pengalaman yang lebih rendah. Akibatnya seperti diulas sebelumnya, tingkat pengangguran yang paling konsisten adalah mereka yang rendah pengalaman dan rendah pendidikan.

Di samping hal-hal di atas, ada satu faktor lain yang menyebabkan perusahaan enggan menyerap tenaga kerja tambahan. Mayoritas perusahaan menyatakan bahwa lebih baik mempekerjakan pegawai yang sudah ada dengan tambahan waktu atau lembur (Grafik III.30). Begitu pun ternyata pekerja memiliki pendapat yang kurang lebih sama dengan perusahaan. Kelihatannya perusahaan memandang bahwa pemberian upah lembur lebih ekonomis dibanding mempekerjakan pekerja baru.

\section{KESIMPULAN DAN IMPLIKASI KEBIJAKAN}

\section{V.1. Kesimpulan}

Pada intinya, studi ini menyimpulkan bahwa persistensi pengangguran yang terjadi selama ini di Indonesia termasuk kategori disequilibrium persistent unemployment without self correcting mechanism, yang berarti bahwa persistensi terjadi di luar kesetimbangan pasar tenaga kerja serta tidak memiliki mekanisme automatis untuk menuju titik kesetimbangan. Selain itu, persistensi merupakan akibat dari lambatnya proses akumulasi modal, kekakuan upah, semakin lamanya pencarian lapangan kerja (job search) dan berbagai kelembaman yang diakibatkan oleh faktor kelembagaan pasar tenaga kerja.

Sebuah fenomena persistensi pengangguran bisa terjadi di luar titik kesetimbangan. Hal ini dimungkinkan terjadi pada saat kekuatan dan tata kelembagaan pasar tenaga kerja tidak lagi sepenuhnya berfungsi dalam menyeimbangkan penawaran dan permintaan tenaga kerja. Selain itu persistensi di Indonesia ditandai dengan lebih dominannya komponen tren dibandingkan komponen siklik. Persistensi jenis ini ditandai dengan peningkatan trend unemployment yang merupakan pergeseran dalam natural rate of unemployment dari waktu ke waktu.

Dikatakan sebagai tidak memiliki self correcting mechanism karena hampir bisa dipastikan bahwa sulit untuk kembali ke keseimbangan jangka panjangnya. Dengan sifat yang seperti ini, sangat sulit untuk mengharapkan mekanisme pasar dapat secara automatis mengatasi pengangguran. Dengan kata lain perlu adanya hands on strategy dari pemerintah.

Sumber masalah persistensi pengangguran yang pertama adalah lambannya akumulasi modal. Dalam era pascakrisis, akumulasi kapital menjadi bertambah lamban yang ditunjukan dengan rasio investasi yang lebih rendah dibanding era sebelum krisis. Diperkirakan rendahnya 
rasio investasi tersebut berasosiasi dengan beberapa hal berikut ini. Pertama, terlalu lambatnya proses restrukturisasi perusahaan yang dilakukan oleh BPPN. Kedua, bersamaan dengan terjadinya krisis terjadi juga pelarian modal dan pelarian pemilik modal. Ketiga, pada saat krisis banyak perusahaan dan wirausaha yang mengalami kebangkrutan dan memerlukan waktu untuk bangkit seperti semula. Keempat, ketersediaan kredit investasi dari perbankan masih belum mencapai tingkat sebelum krisis. Kelima, sektor finansial terutama pasar modal telah menjadi kontraproduktif terhadap sektor riil di mana return dari aset finansial jauh lebih tinggi dibanding keuntungan dari sektor riil.

Sumber masalah yang kedua adalah kekakuan upah nominal dan riil. Kekakuan upah nominal telah membuat upah gagal menjadi market clearing mechanism sehingga tingkat pengangguran menjadi lebih tinggi dari seharusnya. Ada tiga hal yang menjadi penyebabnya di Indonesia yakni: (1) biaya untuk menurunkan upah nominal dianggap lebih tinggi dibandingkan manfaatnya, dan (2) indeksasi upah minimum terhadap inflasi baik secara backward maupun forward. Tetapi hasil survei memperlihatkan bahwa penyebab yang pertama merupakan yang paling penting. Selain itu, tidak ada bukti kuat yang memperlihatkan bahwa upah relatif dan upah efisiensi merupakan sumber kekakuan upah nominal.

Fakta berikutnya yang jauh lebih penting adalah fenomena kekakuan upah riil. Fenomena ini terjadi manakala upah riil yang dibayarkan kepada pekerja melebihi marginal productivity of labor. Agar pengangguran bisa diturunkan maka pertumbuhan upah riil harus lebih rendah dibanding pertumbuhan warranted wage. Kenyataanya, keduanya memiliki tingkat pertumbuhan yang sama, sehingga bisa disimpulkan bahwa upah riil gagal melakukan penyesuaian atau bersifat kaku.

Sumber persistensi yang ketiga adalah semakin lamanya waktu yang dibutuhkan untuk pencarian kerja (job search). Pencarian kerja sangat dipengaruhi oleh beberapa faktor berikut ini: sectoral shift, friksi, mismatch, ketidaksempurnaan informasi, geografhic barier, dan upah reservasi. Perubahan komposisi sektoral (sectoral shift) dalam perekonomian nasional mengarah pada membesarnya pangsa sektor manufaktur dan jasa. Padahal kedua sektor tersebut memiliki elastisitas penyerapan tenaga kerja yang lebih kecil dibandingkan sektor pertanian. Akibatnya limpahan tenaga kerja dari sektor pertanian tidak bisa tertampung di kedua sektor tersebut. Meningkatnya pengangguran friksional biasanya ditandai oleh semakin sulitnya melakukan perpindahan pekerjaan. Kesulitan dalam mencari pekerjaan yang sesuai dengan kualifikasi juga dialami oleh para penganggur. Fenomena ini dikenal sebagai mismatch yang kemungkinan besar merupakan akibat dari ketidaksesuaian sistem pendidikan dengan perubahan struktural dalam perekonomian. 
Hambatan informasi terutama dihadapi mereka yang berpendidikan rendah. Mereka pada umumnya mendapatkan informasi lowongan kerja dari mulut ke mulut dan hanya sedikit saja yang melalui media massa. Faktor berikutnya yang menjadi penghambat pencarian kerja adalah faktor geografis di mana terdapat disparitas yang tajam dalam pengangguran di tingkat provinsi. Provinsi yang relatif lebih maju di mana sektor manufaktur dan jasa memiliki pangsa yang lebih besar cenderung memiliki tingkat pengangguran yang lebih tinggi dan lebih persisten.

Faktor terakhir yang mungkin paling penting dalam mempengaruhi lamanya pencarian kerja adalah upah reservasi (reservation wage). Yang paling mengejutkan adalah kenyataan bahwa upah reservasi di antara para penganggur yang tidak terdidik cenderung lebih tinggi dibanding upah minimum.

Selain faktor-faktor di atas, terdapat hal-hal lainnya yang secara bersamaan dapat mempengaruhi kekakuan upah dan pencarian kerja. Faktor-faktor tersebut dapat dikelompokan menjadi tiga, yakni: regulasi, peran serikat pekerja, dan mekanisme penyesuaian.

Di antara aspek regulasi yang paling kelihatan pengaruhnya terhadap kekakuan upah dan pencarian kerja adalah aturan mengenai pesangon dan jaminan sosial. Peratuan mengenai pesangon secara potensial akan meningkatkan upah reservasi yang pada gilirannya memperburuk persistensi pengangguran. Kebijakan mengenai jaminan sosial tenaga kerja walaupun sudah menjadi kewajiban bagi setiap perusahaan untuk menyediakannya, tetapi ada sekitar sepertiga dari perusahaan yang tidak mematuhi. Kemungkinan besar perusahaan merasa bahwa beban premi yang harus ditanggung terlalu tinggi.

Peran serikat pekerja ditengarai sebagai salah satu sumber persistensi yang cukup penting. Serikat pekerja merupakan kekuatan monopoli yang dapat mempengaruhi secara kolektif keputusan pengupahan dan kebijakan pemutusan hubungan kerja yang dilakukan oleh perusahaan. Hal ini disebut sebagai collective bergaining.

Yang paling mengherankan adalah persepsi dari para penganggur mengenai peran serikat pekerja. Seharusnya, mereka memiliki sifat yang antipati. Tetapi data survei menunjukan bahwa penganggur memiliki rasa simpati terhadap serikat pekerja dan memandang eksistensinya sebagai sesuatu hal yang bermanfaat. Padahal, serikat pekerja memiliki kontribusi dalam mempersulit posisi para pencari kerja. 


\section{V.2. Implikasi Kebijakan}

Beberapa implikasi penting dari berbagai temuan yang telah didiskusikan di atas. Pertama, peningkatan pengangguran yang terjadi selama ini kecil kemungkinannya merupakan akibat dari rendahnya tingkat pertumbuhan. Oleh karena itu, perbaikan dalam tingkat pertumbuhan menjadi tidak cukup untuk mengatasi masalah pengangguran.

Kedua, pemerintah tampaknya tidak bisa mengandalkan mekanisme pasar secara murni untuk mengatasi pengangguran. Harus ada hands on strategi yang didesain secara khusus untuk mengembalikan tingkat pengangguran ke arah kesetimbangan jangka panjang. Pengalaman di Eropa menunjukan tingkat pengangguran akan cenderung memburuk dan berlangsung lama jika tidak ditangani secara tepat. Merupakan kepentingan rakyat Indonesia untuk tidak terjebak pada situasi yang mirip dengan pola pengangguran Eropa Barat.

Ketiga, untuk mengatasi masalah lambannya akumulasi modal perbankan harus diarahkan untuk lebih menggenjot kredit investasi. Hal ini bisa dilakukan dengan menciptakan insentif khusus bagi perbankan seperti penilaian Aktiva Tertimbang Menurut Risiko (ATMR) yang lebih rendah. Selain itu, untuk lebih memproduktifkan hubungan sektor riil dengan pasar modal tampaknya kapitalisasi pasar perlu didorong lebih dari sisi jumlah saham bukan dari sisi harga. Fasilitas pajak khusus bisa diberikan kepada perusahaan yang melakukan penerbitan saham di Bursa Efek Indonesia.

Keempat, fokus kebijakan moneter tampaknya yang paling relevan untuk mengatasi kekakuan upah nominal adalah inflation targeting. Hal ini dilandasi oleh temuan yang mengindikasikan keterbatasan penggunaan kebijakan moneter yang bersifat ekspansif dalam mengatasi pengangguran. Kebijakan moneter yang berusaha mendorong anticipated inflation maupun unanticipated inflation sama sekali tidak efektif karena akan dikompensasi oleh mekanisme indeksasi secara backward maupun forward yang terlalu berlebihan. Yang tercipta malahan adalah inflasi yang persisten tanpa memiliki pengaruh terhadap tingkat pengangguran. Dalam situasi seperti ini, kebijakan inflation targeting dengan sasaran inflasi jangka panjang yang lebih rendah menjadi lebih relevan.

Kelima, untuk mengatasi masalah yang diciptakan oleh kekakuan upah riil maka pemerintah bisa mendorong warranted real wage untuk tumbuh jauh lebih cepat. Syarat utamanya adalah meningkatkan total factor pruductivity (TFP). Untuk meningkatkan TFP perlu dilakukan langkah-langkah sebagai berikut: (1) melakukan akselerasi akumulasi modal, (2) meningkatkan efisiensi investasi, dan (3) meningkatkan kualitas sumberdaya manusia (SDM). Ketiganya tersebut tidak bisa dilakukan dalam jangka pendek. 
Keenam, perlu adanya inisiatif khusus untuk memperbaiki kualitas pertumbuhan dengan cara mendorong sebagian sektor manufaktur dan jasa yang bersifat labor intensive. Akan tetapi kesulitannya adalah pemilihan teknologi produksi sepenuhnya berada di tangan perusahaan yang murni didorong oleh motif mencari keuntungan. Dengan demikian yang harus dilakukan oleh pemerintah adalah mengembangkan insentif untuk pengembangan teknologi padat tenaga kerja dan disinsentif untuk teknologi padat modal.

Ketujuh, untuk memperkecil terjadinya mismatch maka perlu ada perubahan yang mendasar dalam sistem pendidikan nasional menuju sistem yang berbasis kepada keahlian. Pendidikan kejuruan harus lebih dikembangkan. Akan tetapi masalah ini tidak bisa diselesaikan dalam waktu yang relatif singkat karena membutuhkan penyediaan infrastruktur dan pengajar. Selain itu, stigma yang bekerja di masyarakat bahwa pendidikan kejuruan lebih inferior harus dikikis.

Kedelapan, implikasi dari hambatan geografis dalam pencarian kerja adalah bahwa tidak cukup bila pemerintah berupaya menjalankan program penciptaan lapangan kerja yang sangat generik tanpa membedakan karakteristik pengangguran di setiap daerah. Dengan kata lain setiap daerah harus memiliki program anti pengangguran sendiri. Secara implisit, hal ini menuntut kreativitas dari pemerintah daerah. 
halaman ini sengaja dikosongkan 


\section{DAFTAR PUSTAKA}

Arumpalam, W., A. L. Booth, dan M. P. Taylor. 2000. Unemployment Persistence. Oxford Economic Papers 52 (2000), 24-50. Oxford University Press.

Barro, R.J. 1988. The Persistence of Unemployment. The American Economic Review, Vol. 78. No. 2. Papers and Proceedings of the One-Hundreth Annual Meeting of the American Economy Association (May, 1988), pp. 32-37.

Bianchi, M., G. Zoega. 1998. Unemployment Persistence: Does the Size of the Shock Matter?. Journal of Applied Economics. Vol. 13 No. 3 (May-Jun, 1998), pp. 283-304. John Wiley \& Sons.

Blanchard, O. 1991. Wage Bargaining and Unemployment Persistence. Journal of Money, Credit and Banking, Vol. 23, No. 3, Part 1 (Aug, 1991), pp. 277-292. Ohio State University Press. Blanchard, O.J. dan L.H. Summers. 1986. Hysteresis and the European unemployment problem. NBER Working Paper/1950, Cambridge, MA.

Brunello, G. 1990. Hysteresis and "the Japanese unemployment problem": a preliminary investigation. Oxford Economic Papers 42, 483-500.

Calmfors, L. dan B. Holmlund. 2000. Unemployment and economic growth : a partial survey. Swedish Economic Policy Review 7 (2000) 107-153.

Dickey, D.A. dan A.W. Fuller. 1981. Likelihood ratio statistics for autorregresive time series with a unit root. Econometrica 49, 1057-1072.

Im, K.S., M.H. Pesaran, and Y. Shin. 1997. Testing for unit roots in heterogeneous panels. Mimeo, DAE University of Cambridge.

Feve, P., P. Y. Henin, dan P. Jolivaldt. 2002. Testing for hysterisis: Unemployment persistence and wage adjustment. Empirical Economics (2003) 28 : 535-552. Springer-Verlag.

Levin, A. dan C.F. Lin. 1992. Unit-root test in panel data: asymptotic and finite sample properties. WP, University of California at San Diego.

Linblad, H. Persistence in Swedish Unemployment Rates. Working Paper Department of Economics 1997-01-21. University of Stockholm, 10691 Stockholm. Sweden.

MacKinnon, J. G. 1991. Critical Values for Cointegration Tests. Chapter 13 in R. F. Engle and C. W. J. Granger (eds.), Long-run Economic Relationships: Readings in Cointegration, Oxford: Oxford University Press. 
MacKinnon, J. G. 1996. Numerical Distribution Functions for Unit Root and Cointegration Tests. Journal of Applied Econometrics, 11, 601-618.

Maddala, G.S. dan S. Wu., 1999. A comparative study of unit roots tests with panel data and a new simple test. Oxford Bulletin of Economics and Statistics Special Issue, 631-652.

Mitchell, W.F. 1993. Testing for unit roots and persistence in OECD unemployment rates. Applied Economics 25, 1489-1501.

Monastiriotis, V. 2006. Employment flexibility and UK regional unemployment : persistence and macroeconomic shocks. Employment Relations Research Series No. 65. Department of Trade and Industry.

Song, F.M. dan Y. Wu. 1997. Hysteresis in unemployment: evidence from 48 U.S. states. Economic Inquiry 35, 235-244.

Steinier, V. 2001. Unemployment persistence in the West German labour market : negative duration dependence or sorting?. Oxford Bulletin Economice and Statistics, 63, 1 (2001) 0305-9049. Blackwell Publishers. Routledge Taylor \& Francis Group.

Tolvi, J. 2003. Unemployment persistence of different labour force groups in Finland. Applied Economics Letter, 2003, 10, 455-458.

Wu, Z. 2003. The Persistence of Regional Unemployment : evidence from China. Applied Economics, 2003, 35, 1417-1421. Routledge Taylor \& Francis Group. 